Review

\title{
Quantification of Atmospheric Ammonia Concentrations: A Review of Its Measurement and Modeling
}

\author{
Arshad Arjunan Nair *(D) and Fangqun Yu (D) \\ Atmospheric Sciences Research Center, State University of New York at Albany, 251 Fuller Road, \\ Albany, NY 12203, USA; fyu@albany.edu \\ * Correspondence: aanair@albany.edu
}

Received: 19 August 2020; Accepted: 30 September 2020; Published: 13 October 2020

\begin{abstract}
Ammonia $\left(\mathrm{NH}_{3}\right)$, the most prevalent alkaline gas in the atmosphere, plays a significant role in $\mathrm{PM}_{2.5}$ formation, atmospheric chemistry, and new particle formation. This paper reviews quantification of $\left[\mathrm{NH}_{3}\right]$ through measurements, satellite-remote-sensing, and modeling reported in over 500 publications towards synthesizing the current knowledge of $\left[\mathrm{NH}_{3}\right]$, focusing on spatiotemporal variations, controlling processes, and quantification issues. Most measurements are through regional passive sampler networks. [ $\left.\mathrm{NH}_{3}\right]$ hotspots are typically over agricultural regions, such as the Midwest US and the North China Plain, with elevated concentrations reaching monthly averages of 20 and 74 ppbv, respectively. Topographical effects dramatically increase $\left[\mathrm{NH}_{3}\right]$ over the Indo-Gangetic Plains, North India and San Joaquin Valley, US. Measurements are sparse over oceans, where $\left[\mathrm{NH}_{3}\right] \approx$ a few tens of pptv, variations of which can affect aerosol formation. Satellite remote-sensing (AIRS, CrIS, IASI, TANSO-FTS, TES) provides global $\left[\mathrm{NH}_{3}\right]$ quantification in the column and at the surface since 2002. Modeling is crucial for improving understanding of $\mathrm{NH}_{3}$ chemistry and transport, its spatiotemporal variations, source apportionment, exploring physicochemical mechanisms, and predicting future scenarios. GEOS-Chem (global) and FRAME (UK) models are commonly applied for this. A synergistic approach of measurements $\leftrightarrow$ satellite-inference $\leftrightarrow$ modeling is needed towards improved understanding of atmospheric ammonia, which is of concern from the standpoint of human health and the ecosystem.
\end{abstract}

Keywords: review; ammonia; $\mathrm{NH}_{3}$; modeling; measurement; quantification; atmospheric chemistry; particle formation; $\mathrm{PM}_{2.5}$

\section{Introduction}

Atmospheric ammonia $\left(\mathrm{NH}_{3}\right)$, mainly from agriculture with additional sources in industrial and vehicular emissions, plays a key role in many aspects of our environment by virtue of its alkalinity, reactivity, solubility, and abundance. In recent years, there has been an increase in atmospheric ammonia concentrations $\left(\left[\mathrm{NH}_{3}\right]\right)$ mainly due to increased land use for agriculture [1-3] to support our burgeoning population. This has generated concern about its negative impacts on the climate and human health. This is especially due to the role of $\mathrm{NH}_{3}$ in the formation of $\mathrm{PM}_{2.5}$ through its neutralization of acidic species in the atmosphere. $\mathrm{NH}_{3}$ has been receiving increasing attention recently due to its potential enhancement of atmospheric new particle formation [4,5]. The impacts of $\mathrm{NH}_{3}$ and the resultant particulate matter on human health [6], ecosystem, and climate deem understanding its concentration in the atmosphere important. $\mathrm{NH}_{3}$ has the following major impacts on the environment. Firstly, $\mathrm{NH}_{3}$ is the greatest contributor to reactive nitrogen deposition [7-10] in several regions across the globe. Such deposition can contribute to eutrophication of aquatic and 
terrestrial ecosystems [11,12], which may be enhanced due to the greater bioavailability of $\mathrm{NH}_{3}$ or ammonium $\left(\mathrm{NH}_{4}^{+}\right)$compared to other reactive nitrogen species [13-15]. Acidification via nitrification, i.e., the conversion of $\mathrm{NH}_{3}$ to nitrite $\left(\mathrm{NO}_{2}{ }^{-}\right)$and then to nitrate $\left(\mathrm{NO}_{3}{ }^{-}\right)$, can also occur $[11,12,16-21]$. For instance, $1 \mathrm{~mol}$ of ammonium sulfate $\left(\left(\mathrm{NH}_{4}\right)_{2} \mathrm{SO}_{4}\right)$ can potentially release 4 mols of acidity, i.e., $\mathrm{H}^{+}$ ions. Secondly, $\mathrm{NH}_{3}$ can have negative impacts on the ecosystem by direct toxicity, expected above a critical threshold of $\sim 4 \mathrm{ppbv}$ of $\left[\mathrm{NH}_{3}\right]$ [22], which is frequently the case in several countries. These impacts can be on vegetation $[12,23]$ through direct damage of stomata, leaves, and other plant surfaces, and biodiversity changes or loss owing to preferential direct uptake of $\mathrm{NH}_{3}$ by certain plant species, as well as affecting plant resilience to abiotic and biotic stressors. Direct impacts on livestock [24-26] and humans $[27,28]$ can be through exothermic and alkaline effects on epithelial tissues of the eyes and the respiratory tract. Thirdly, $\mathrm{NH}_{3}$ plays a role in determining the total particle mass and number concentrations, apart from the extent of neutralization of atmospheric particles [4,29-31]. The contribution of $\mathrm{NH}_{4}{ }^{+}$to particulate matter is comparable to that of other inorganic species, such as $\mathrm{NO}_{3}{ }^{-}$and sulfate $\left(\mathrm{SO}_{4}{ }^{2-}\right)$, as seen from modeling [32-34] and measurements $[9,35,36]$. Furthermore, Tsigaridis et al. [33] indicate that the increase in $\mathrm{NH}_{4}{ }^{+}$absolute $(0.13 \rightarrow 0.37 \mathrm{Tg})$ and relative $(0.5 \% \rightarrow 1.3 \%)$ contribution to aerosol burden from pre-industrial to present-day times, which is supported by observations from ice core studies [37-39]. $\mathrm{NH}_{3}$ also affects the hygroscopicity of particles, an important physicochemical property determining particles' water carrying capacity. Finally, $\mathrm{NH}_{3}$ can significantly enhance the nucleation rate of aerosol particles through sulfuric acid vapor condensation [4,5,40-42], with implications to aerosol indirect radiative forcing. Furthermore, gas-particle partitioning of $\mathrm{NH}_{3}$ to form $\mathrm{NH}_{4}{ }^{+}$salts can contribute to the continued growth of these newly-formed aerosol particles. Although $\mathrm{NH}_{3}$ shows thermodynamic preference for neutralization of $\mathrm{H}_{2} \mathrm{SO}_{4}$ to form solid $\left(\mathrm{NH}_{4}\right)_{2} \mathrm{SO}_{4}$, formation of the semi-volatile $\mathrm{NH}_{4} \mathrm{NO}_{3}$ when there is small supersaturation of $\mathrm{NH}_{3}$ and $\mathrm{HNO}_{3}$ can contribute to rapid particle growth [43]. Additionally, $\mathrm{NH}_{3}$ that remains in the gas-phase can dissolve into the aerosol water and increase its $\mathrm{pH}$, thereby increasing the solubility of $\mathrm{HNO}_{3}$ and other acidic species. Considering that the largest uncertainties in climate modeling come from aerosols [44], the role of $\mathrm{NH}_{3}$ in aerosol nucleation, growth, and characteristics is especially important. While ammonia itself has a very short atmospheric lifetime of a few hours to a day owing to rapid deposition and particle uptake, its particulate forms too have relatively short atmospheric lifetimes of under a week [45-47]; this further implies that there may be more significant regional climate impacts [48].

Due to its importance, quantification of atmospheric ammonia concentrations ([NH3]), mostly through in situ measurements, satellite remote sensing, and modeling, has been reported in hundreds of publications. Here we review these previous studies, with the following aims: (1) aggregating current knowledge from the varied techniques for quantification of $\left[\mathrm{NH}_{3}\right],(2)$ identifying the variability and trends in $\left[\mathrm{NH}_{3}\right]$, (3) understanding these features in context of the processes that govern the concentration of ambient atmospheric $\mathrm{NH}_{3}$, and (4) examining the issues with these quantification approaches and the current and required attempts at resolving these. To the best of our knowledge, there has been no comprehensive review of previous studies of quantification of atmospheric $\left[\mathrm{NH}_{3}\right]$ concentrations.

In the present section, we have provided the motivation for this review and a survey of literature examining atmospheric $\mathrm{NH}_{3}$ and its effects. Figure 1 outlines this review; Section 2 details the various measurement techniques of $\left[\mathrm{NH}_{3}\right]$. Some key studies and their results are discussed here. Section 3 discusses the modeling of $\mathrm{NH}_{3}$ and the processes that affect its concentration in the atmosphere. This section also examines the validation of modeling studies with observations and some insights that this provides. Section 4 paints a picture of the spatial distribution on the global and regional scales. Section 5 examines the temporal trends in $\left[\mathrm{NH}_{3}\right]$ on varying scales from several studies. Issues with the various approaches of quantifying $\left[\mathrm{NH}_{3}\right]$ are discussed in each corresponding section and summarized in Section 6, which also concludes with the future steps and challenges in the quantification of atmospheric $\mathrm{NH}_{3}$. 


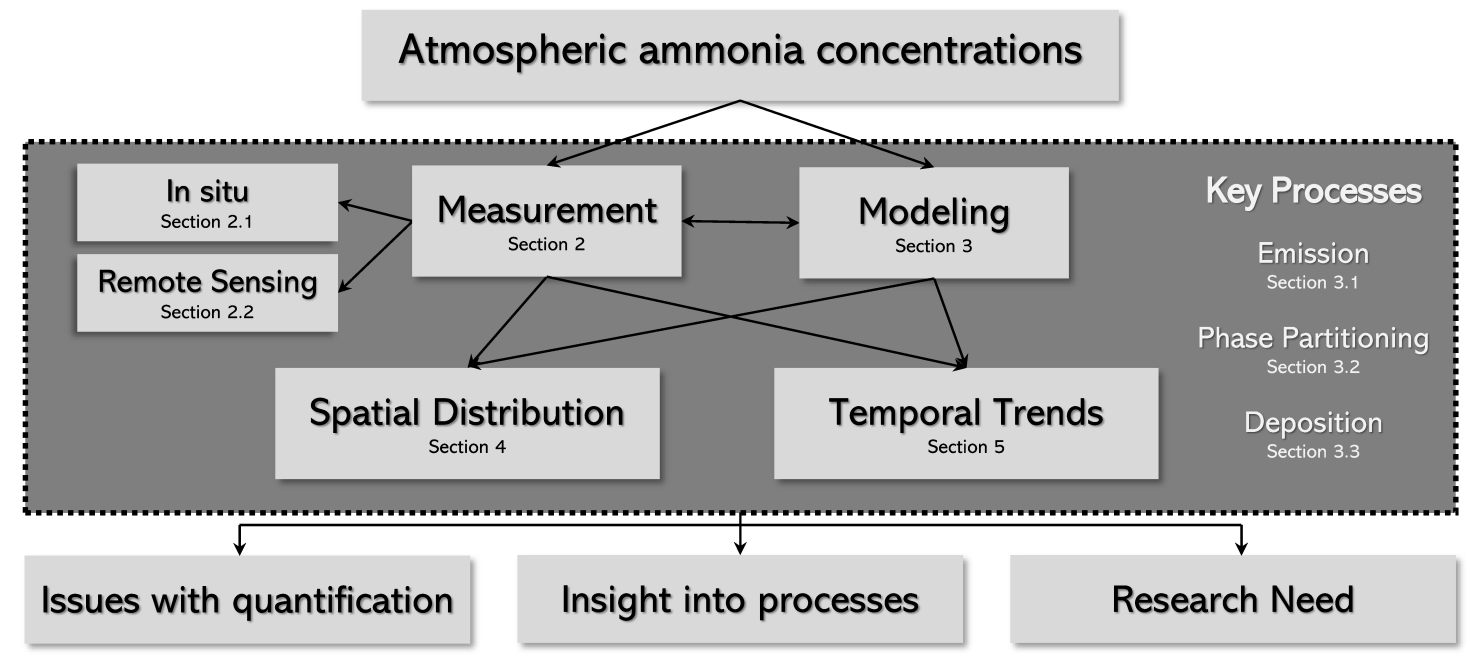

Figure 1. A schematic of the discussion in this review paper.

\section{Measurement of $\left[\mathrm{NH}_{3}\right]$}

\subsection{In Situ Measurements}

It is natural that the first measurements of $\mathrm{NH}_{3}$ in the gas-phase were made through ground-based instrumentation. The earliest detailed measurements of atmospheric $\mathrm{NH}_{3}$ were made by Egner and Eriksson [49] over Scandinavia. "Ammonia and nitrate are determined in one aliquot of the sample by successive destillations in all-glass stills with excess of sodium hydroxide, and Devarda's alloy. The final estimate of ammonia is made with a special Nessler technique, using a photoelectric colorimeter." However, their approach did not distinguish between the gas-phase $\mathrm{NH}_{3}$ and the aerosol $\mathrm{NH}_{4}{ }^{+}$. The first measurements of $\left[\mathrm{NH}_{3}\right]$ solely in the gas-phase were performed by Junge [50] over locations in Florida and Hawaii, with an important realization that the $\mathrm{NH}_{4}{ }^{+}$aerosol is formed from atmospheric $\mathrm{NH}_{3}$. Over the next six decades, there have been advancements in measurement methods, initially aiming at distinguishing gas and aerosol phases and the later goal of realizing continuous measurement of $\left[\mathrm{NH}_{3}\right]$.

Towards the first goal, the first major development was the filter pack method [51], which filtered out aerosol particles on a Teflon pre-filter before collection of $\mathrm{NH}_{3}$ on an acid-coated filter. However, there were issues with volatility of the aerosol $\mathrm{NH}_{4}{ }^{+}$causing positive error, and humidity causing $\mathrm{NH}_{3}$ deposition in the pre-filter and consequently a negative error in $\mathrm{NH}_{3}$ measurement [52]. In 1979, Martin Ferm discussed a "method for determination of atmospheric ammonia" based on the differential diffusion rates to a surface for gas molecules and aerosols [53]. Using an oxalic acid-coated tube, separation of $\mathrm{NH}_{3}$ (trapped onto the tube walls) and $\mathrm{NH}_{4}{ }^{+}$aerosols can be achieved. Many of the later refinements into $\mathrm{NH}_{3}$ detection instruments have been based on this simple denuder technique. Continuous measurement of $\mathrm{NH}_{3}$ was achieved by Wyers et al. [54], where a fully automated continuous flow rotating wet denuder was developed.

Numerous ground-based measurements of atmospheric $\mathrm{NH}_{3}$ are listed in Table S1. The observations made in the reviewed literature are synthesized into Figure 2, with a global map of the average surface $\left[\mathrm{NH}_{3}\right]$ measurements ranging from $<1 \mathrm{ppbv}$ in remote continental and oceanic areas to $>24 \mathrm{ppbv}$, typically over regions of intensive agriculture. Longer detailed measurements have been made over the United States, Europe, and China. Some of the important results and inferences from these studies are discussed in detail in subsequent sections. From Table S1 and Figure 2 we note that most in situ measurements of $\left[\mathrm{NH}_{3}\right]$ are over land. Most surface-based measurements over land are made in North America and Europe. Systematic measurements have been made through $\mathrm{NH}_{3}$ monitoring networks (see Table 1), which have been established after identifying increasing $\mathrm{NH}_{4}{ }^{+}$ and $\mathrm{NH}_{3}$ trends and their effects on $\mathrm{PM}_{2.5}$ formation. In the US, the Ammonia Monitoring Network 
(AMoN; Puchalski et al. [55], Butler et al. [56]) provides biweekly integrated surface measurements of $\left[\mathrm{NH}_{3}\right]$ from a network of 123 sites, with the longest measurement period from October 2007 to the present and an average measurement duration of 7 years. $\mathrm{NH}_{3}$ is collected using a passive diffusion sampler and subsequently its laboratory measurement is conducted by sonic dislodgment of $\mathrm{NH}_{4}{ }^{+}$ions from the phosphoric acid sorbent and subsequent flow injection analysis (FIA). In the UK, the National Ammonia Monitoring Network (NAMN) was established in September 1996 and provides monthly integrated surface $\left[\mathrm{NH}_{3}\right]$ data from a network of 72 active sites. The NAMN uses a combination of an active diffusion denuder method (DELTA samplers: DEnuder for Long Term Atmospheric, Sutton et al. [57]) and passive samplers (ALPHA: Adapted Low-cost Passive High-Absorption sampler, Tang et al. [58]). In the Netherlands, the Dutch National Air Quality Monitoring Network (LML: Landelijk Meetnet Luchtkwaliteit) and the Measuring Ammonia in Nature Network (MAN) have been making measurements of $\left[\mathrm{NH}_{3}\right]$ across the Netherlands since 1993 and 2005, respectively. The LML reports hourly $\left[\mathrm{NH}_{3}\right]$ since 1993 at eight sites and since 2014 at six sites using continuous-flow denuders (AMORs: Amanda for MOnitoring RIVM; Wyers et al. [54]) and currently miniDOAS [59], and in two sites, triplets of passive samplers [60] for monthly mean values. While the LML provides a high temporal resolution, its low spatial distribution is compensated by over 300 sites of MAN that provide monthly passive sampling measurements of $\left[\mathrm{NH}_{3}\right]$. Apart from these $\mathrm{NH}_{3}$ monitoring networks, observations of $\left[\mathrm{NH}_{3}\right]$ have been made over the ocean in certain campaigns. However, such in situ measurements are significantly fewer compared to those over land. While this has been justified by their distance from human settlements and there being orders of magnitude less $\mathrm{NH}_{3}$ over oceans compared to land, recent evidence from Yu et al. [5] suggests that $\mathrm{NH}_{3}$ even in pptv levels can have a significant effect on atmospheric new particle formation.

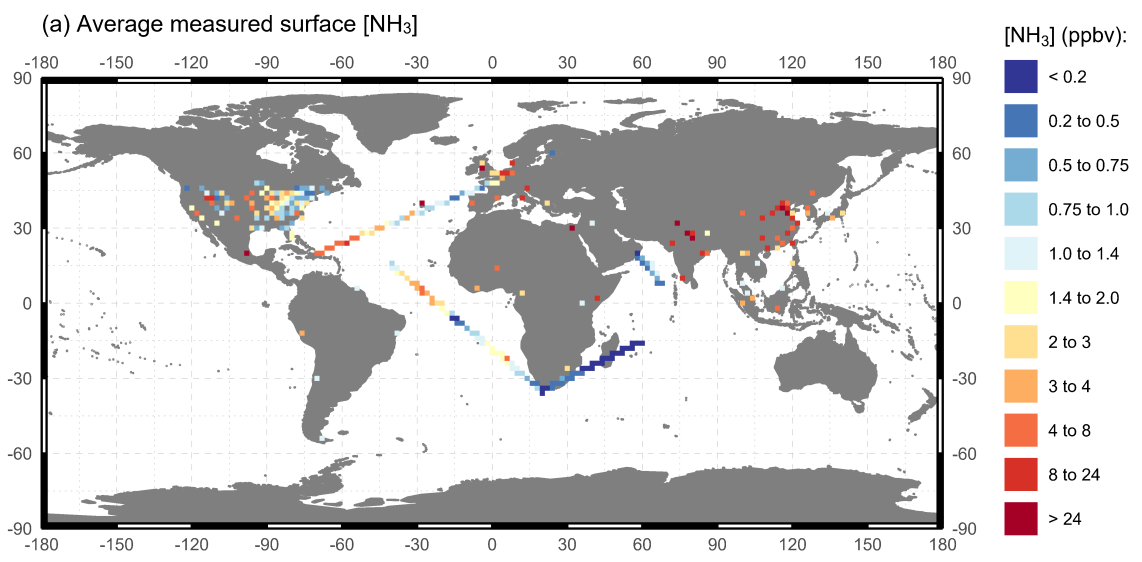

(b) Duration of in situ measurements

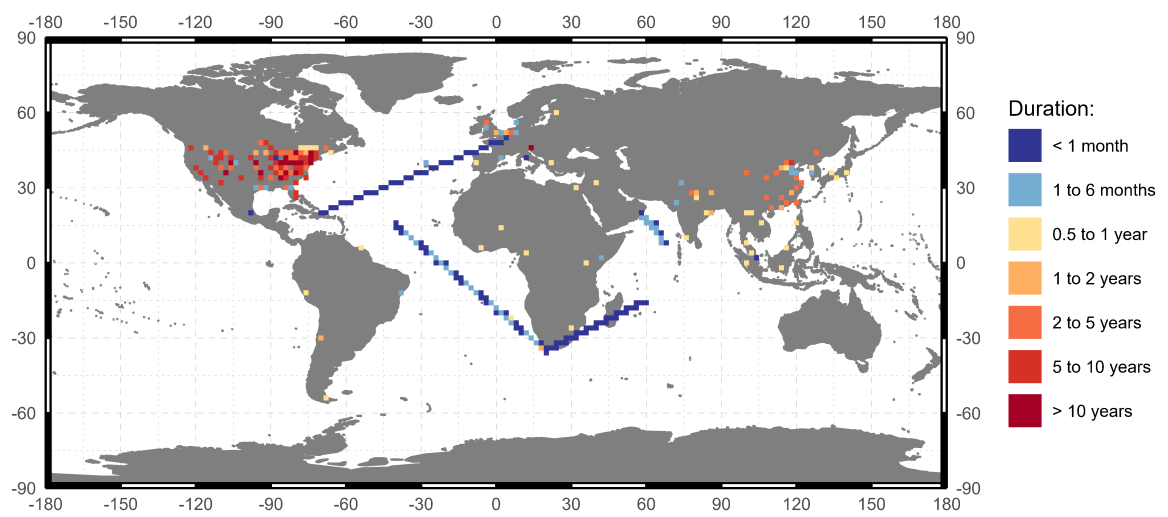

Figure 2. Global in situ measurements reviewed in this paper aggregated to $1^{\circ} \times 1^{\circ}$ resolution. 
Table 1. Details of long-term $\left[\mathrm{NH}_{3}\right]$ measurement networks and their data access links.

\begin{tabular}{lllll}
\hline Network & Location & Start Year & Sites & Data Access \\
\hline AMoN & US & 2007 & 123 & http://nadp.slh.wisc.edu/data/AMoN/ \\
AMoN-China & China & 2015 & 53 & https://doi.org/10.1021/acs.est.7b05235 \\
LML & Netherlands & 1993 & 8 & https://www.luchtmeetnet.nl/meetpunten?component=NH3 \\
MAN & Netherlands & 2005 & $300+$ & https://man.rivm.nl/ \\
NAMN & UK & 1996 & 85 & https://uk-air.defra.gov.uk/networks/network-info?view=nh3 \\
NAPS & Canada & 2004 & 7 & http://maps-cartes.ec.gc.ca/rnspa-naps/data.aspx * \\
\hline
\end{tabular}

* At the time of this review, this link did not contain the $\left[\mathrm{NH}_{3}\right]$ data, which should be procurable from Yao and Zhang [61].

In recent years, novel methods of instrumentation have been developed for the measurement of $\left[\mathrm{NH}_{3}\right]$ with a finer temporal resolution. As seen above, most instrumentation deployed in $\mathrm{NH}_{3}$ monitoring networks have poor temporal resolution, to the extent of biweekly sampling for reduced costs. Additionally, offline analysis may introduce errors due to revolatilization of $\mathrm{NH}_{3}$ and human errors. Some recent advances that are being implemented or have the scope of implementation include: chemical ionization mass spectrometers (CIMS), The Quantum Cascade Tunable Infrared Laser Differential Absorption Spectrometer (QC-TILDAS), differential optical absorption spectroscopy (DOAS), and Monitor for AeRosols and GAses in ambient air (MARGA). Chemical ionization mass spectrometers (CIMS) have been developed for fast time resolution measurement of $\mathrm{NH}_{3}$ [62-68]. Compared to other emerging instrumentation, the CIMS technique is highly advantageous due to its fast time response ( $<1 \mathrm{~min})$. However, Nowak et al. [64] note that the absolute level and the variability in the instrumental background are a limitation. QC-TILDAS determines the mixing ratio of $\mathrm{NH}_{3}$ by monitoring the molecule's absorption of radiation at $967 \mathrm{~cm}^{-1}$ [69]. Differential optical absorption spectroscopy (DOAS) works on the linearization of the Lambert-Beer law. With open-path arrangement, DOAS provides a contact-free technique for in situ measurement of $\left[\mathrm{NH}_{3}\right]$, within the 203.7-227.8 nm UV wavelength range over path lengths up to $100 \mathrm{~m}$ [70-73]. To overcome the issues with instrument performance [74,75], significant improvements have been made over recent years, mainly by Volten et al. [76] and Sintermann et al. [77], which improve the reliability as well as reduce the cost of this instrument. The Monitor for AeRosols and GAses in ambient air (MARGA; ten Brink et al. [78], Rumsey et al. [79]) is an online instrument that provides hourly time-resolved measurement of water-soluble gases and aerosols using a dual-channel ion chromatograph. These new developments of in situ $\left[\mathrm{NH}_{3}\right]$ measurement techniques are exciting for the insights that can come from continuous and high-resolution data, especially from model-observation comparisons.

For further reading, the reader is directed to some literature on the intercomparison of these varied techniques $[67,68,80-82]$.

\subsection{Satellite Remote Sensing}

$\mathrm{NH}_{3}$ has a remarkable microwave spectrum due to its characteristic "ammonia inversion" [83]. The molecule has a trigonal pyramidal shape with protons on the three points on the base and nitrogen on the top/bottom. This and the fortuitous distance (crossable tunneling barrier) between the protons on the base, allow for nitrogen to pass through the base and change the orientation of the molecule. This causes a strong absorption when microwave/IR photons cause the rapid flipping between the upward pyramidal and downward pyramidal states. Another outcome of the inversion is an inversion doubling, where the infrared spectrum undergoes doubling due to the two possible positions of the nitrogen atoms. Now this opens a whole new avenue for satellite remote sensing of $\mathrm{NH}_{3}$ in the gas-phase. The unique IR spectrum of $\mathrm{NH}_{3}$ can make it distinguishable from other chemical species and background noise. With the plethora of infrared spectrometers available in orbit around Earth, providing the possibility of continuous, real-time, global measurement, it was inevitable that this feature of the $\mathrm{NH}_{3}$ molecule would be tapped into.

The first attempt was when Beer et al. [84] used infrared radiances measured by the Tropospheric Emission Spectrometer (TES) onboard the EOS Aura satellite to infer $\left[\mathrm{NH}_{3}\right]$ from the spectral residual 
differences (calculated as per Rodgers and Connor [85]) in the region of $960-972 \mathrm{~cm}^{-1}$. This was a demonstration of the possibility of detecting $\mathrm{NH}_{3}$ from nadir viewing remote sensing instruments. Due to the limitations of the TES-its small geographic coverage and consequent inability to provide daily coverage-attention was shifted to the Infrared Atmospheric Sounding Interferometer (IASI) onboard the MetOp-A satellite. Although it had a poorer spectral resolution than the TES, it provided a broader spatial coverage. Clarisse et al. [86] made the first annual "global $\mathrm{NH}_{3}$ integrated concentrations retrieved from satellite measurements." Expectedly, there has been a subsequent flurry of activity (see Table 2) in using satellite remote sensing to measure ambient $\mathrm{NH}_{3}$ in the atmosphere.

Satellite remote sensing is capable of capturing spatiotemporal variations in columns as well as surface $\mathrm{NH}_{3}$ concentrations [86-90]. For instance, Heald et al. [91] found underestimation of $\mathrm{NH}_{3}$ emissions in the Midwest during spring and in California using IASI data. This was followed by demonstration of potentially constraining $\mathrm{NH}_{3}$ emissions using TES [ $\mathrm{NH}_{3}$ ] data [92], with improved modeling of $\left[\mathrm{NH}_{3}\right]$ over the US. Thus satellite remote sensing of $\left[\mathrm{NH}_{3}\right]$ can also provide constraints towards improvement of $\mathrm{NH}_{3}$ emission inventory used in chemical transport models.

Table 2. Some satellite remote sensing studies of atmospheric $\mathrm{NH}_{3}$ and instrumentation details.

\begin{tabular}{|c|c|c|c|c|c|c|c|}
\hline Reference & Region & \multicolumn{2}{|c|}{ Instrument } & \multicolumn{3}{|c|}{ Period } & Typical Concentration \\
\hline [84] & Beijing & \multicolumn{2}{|l|}{ TES } & \multicolumn{3}{|c|}{$10 \mathrm{Jul} 2007$} & 5 to $25 \mathrm{ppbv}$ \\
\hline [86] & Global & \multicolumn{2}{|l|}{ IASI } & \multicolumn{3}{|c|}{2008} & \multirow{3}{*}{$5.7 \pm 0.1 \times 10^{16}$ molecules $\mathrm{cm}^{-2}$} \\
\hline [93] & Mediterranean basin & \multicolumn{2}{|l|}{ IASI } & \multicolumn{3}{|c|}{25 Aug 2007} & \\
\hline [94] & Global & & \multicolumn{3}{|c|}{2006 to 2009 (Various) } & \\
\hline [95] & California & \multicolumn{2}{|l|}{ IASI } & \multicolumn{3}{|c|}{2008} & \\
\hline [87] & North Carolina & \multicolumn{2}{|l|}{ TES } & \multicolumn{3}{|c|}{2002} & 1 to $6 \mathrm{ppbv}$ \\
\hline [96] & Global & \multicolumn{2}{|l|}{ IASI } & \multicolumn{3}{|c|}{ Apr 2009 to Mar 2010} & 1 to $6 \mathrm{ppbv}$ \\
\hline [97] & Central Russia & \multicolumn{2}{|l|}{ IASI } & \multicolumn{3}{|c|}{ Jul and Sept 2010} & \multirow[t]{2}{*}{$<8 \times 10^{17}$ molecules $\mathrm{cm}^{-2}$} \\
\hline [92] & US & \multicolumn{2}{|l|}{ TES } & \multicolumn{3}{|c|}{ Apr, Jul, and Oct 2006 to 2009} & \\
\hline [98] & Global & \multicolumn{2}{|l|}{ IASI } & $1 \mathrm{~N}$ & v 2007 to 31 & ct 2012 & $<10^{17}$ molecules $\mathrm{cm}^{-2}$ \\
\hline [99] & California & TES & & $16 \mathrm{~J}$ & $\mathrm{n}$ to 6 Feb 20 & & $<7 \times 10^{16}$ molecules $\mathrm{cm}^{-2}$ \\
\hline [100] & Global & TES & & 200 & & & \\
\hline [101] & Canadian Oil Sands & TES & & Aug & ust to Sept 2 & & \\
\hline [88] & Central US & CrIS & & Jul 2 & 005 & & \\
\hline [102] & Global & IASI & & 200 & to 2013 & & \\
\hline [103] & FTIR Stations & IASI & & 200 & to 2014 & & \\
\hline [104] & Global & MIPA & & 200 & to 2011 & & \\
\hline [89] & Global & AIRS & & Sep & 2002 to Aug & 2015 & \\
\hline [105] & Regional & AIRS & & 200 & to 2016 & & \\
\hline [106] & California & TES & & $7 \mathrm{M}$ & $y$ to 3 Jun 20 & & $21 \pm 17 \mathrm{ppbv}$ \\
\hline [107] & North Africa & IASI & & $7 \mathrm{M}$ & $y$ to 3 Jun 20 & & $\approx 10^{16}{\text { molecules } \mathrm{cm}^{-2}}^{-2}$ \\
\hline [108] & Global & IASI & & 200 & to 2017 & & \\
\hline [109] & Canada & IASI \& & CrIS & Ma) & 2016 & & \\
\hline [110] & Tanzania & IASI & & 200 & to 2017 & & $<4 \times 10^{16}$ molecules $\mathrm{cm}^{-2}$ \\
\hline [111] & Global & IASI & & 200 & to 2017 & & \\
\hline [112] & Global & CrIS & & 201 & to 2017 & & 2 to $10 \mathrm{ppbv}$ \\
\hline [90] & Global & TANS & D-FTS & 200 & to 2014 & & $\approx 10^{16}$ molecules $\mathrm{cm}^{-2}$ \\
\hline Instrument & Satellite & Agency & Peri & & Overpass & Field-of-View & Data Access \\
\hline AIRS & Aqua & NASA & 2002 & 016 & $13: 30$ & $13.5 \mathrm{~km}$ & $\begin{array}{l}\text { https://dx.doi.org/10.5067/ } \\
\text { 06YIT7GX74FN }\end{array}$ \\
\hline CrIS & Suomi-NPP & NOAA & 2012 & 017 & $13: 30$ & $14 \mathrm{~km}$ & $\begin{array}{l}\text { https://hpfx.collab.science.gc. } \\
\text { ca/ mas001/satellite_ext/cris/ } \\
\text { snpp/nh3/v1_5/ }\end{array}$ \\
\hline IASI & MetOp-A/B/C & ESA & 2006 & 020 & 09:30 & $12-39 \mathrm{~km}$ & https://iasi.aeris-data.fr/nh3/ \\
\hline MIPAS & Envisat & ESA & 2002 & 012 & $\mathrm{~N} / \mathrm{A}$ * & $420 \mathrm{~km}$ & $\begin{array}{l}\text { http://share.lsdf.kit.edu/imk/ } \\
\text { asf/sat/mipas-export/ }\end{array}$ \\
\hline TANSO-FTS & GOSAT & JAXA & 2009 & 020 & 13:00 & $10.5 \mathrm{~km}$ & $\begin{array}{l}\text { https://doi.org/10.5194/amt- } \\
\text { 13-309-2020 }\end{array}$ \\
\hline TES & Aura & NASA & 2004 & 018 & $13: 30$ & $5-8 \mathrm{~km}$ & $\begin{array}{l}\text { https://dx.doi.org/10.5067/ } \\
\text { AURA/TES/TL2NH3N.008 }\end{array}$ \\
\hline
\end{tabular}

Abbreviations: FTIR: Fourier-Transform InfraRed spectroscopy, AIRS: Atmospheric Infrared Sounder onboard NASA's (National Aeronautics and Space Administration, US) Aqua satellite, CrIS: Cross-track Infrared Sounder onboard NOAA's (National Oceanic and Atmospheric Administration, US) Suomi NPP satellite, IASI: Infrared Atmospheric Sounding Interferometer onboard the ESA's (European Space Agency) MetOp satellites, MIPAS: Michelson Interferometer for Passive Atmospheric Sounding onboard ESA's Envisat satellite, TANSO-FTS: Thermal And Near infrared Sensor for carbon Observations-Fourier Transform Spectrometer onboard JAXA's (Japan Aerospace eXploration Agency) GOSAT-1, TES: Tropospheric Emission Spectrometer onboard NASA's Aura satellite. Overpass refers to the daytime (when thermal contrast is optimal for $\mathrm{NH}_{3}$ retrieval) crossing of the equator. * Overpass not defined for MIPAS as it makes edge of the atmosphere (limb) $\mathrm{NH}_{3}$ retrievals. 
While satellite-based inference can fill the gaps in observations of $\left[\mathrm{NH}_{3}\right]$ and additionally provide its vertical profile, there are limitations associated with this technique as noted in several studies listed in Table 2. Currently deployed instrumentation is not onboard geostationary satellites, which results in discontinuous temporal measurements. The requirement of a strong thermal contrast reduces reliability of nighttime measurements. The presence of clouds also affects the retrievals. Furthermore, there are issues in the inference of $\left[\mathrm{NH}_{3}\right]$ from the radiances measured by the satellite instrument, with a priori assumptions on the $\left[\mathrm{NH}_{3}\right]$ profile and shape for conversion of radiances into a concentration. This is further compounded by the small signal of $\mathrm{NH}_{3}$ in comparison to the background.

To overcome and understand the above issues, validation studies have been carried out. For the TES, $\mathrm{NH}_{3}$ retrievals were able to capture spatiotemporal patterns observed on the surface by an ammonia monitoring network (CAMNet) in North Carolina [87] and with aircraft measurements [99]. Damme et al. [102] demonstrated the consistency of IASI $\mathrm{NH}_{3}$ retrievals with surface $\mathrm{NH}_{3}$ monitoring networks and aircraft campaigns. These studies show that despite the aforementioned limitations, satellite-based remote-sensing inference of $\left[\mathrm{NH}_{3}\right]$ is an invaluable method of quantification, a tropospheric vertical profiler, and a source apportioner of atmospheric ammonia.

\section{Modeling $\left[\mathrm{NH}_{3}\right]$}

Atmospheric modeling provides another approach to quantify $\left[\mathrm{NH}_{3}\right]$ in the atmosphere. Considering $\mathrm{NH}_{3}$, models can (1) evaluate the environmental impacts of their emissions and depositions, (2) help project the impact of future scenarios, (3) aid in developing our understanding of the processes controlling atmospheric $\left[\mathrm{NH}_{3}\right],(4)$ examine the role of $\mathrm{NH}_{3}$ in affecting atmospheric chemical and physical processes, and (5) study aerosol formation (both mass and number concentrations) dependent on $\left[\mathrm{NH}_{3}\right]$.

The first modeled global distributions of $\left[\mathrm{NH}_{3}\right]$ were derived by Dentener and Crutzen [113] with their development of an $\mathrm{NH}_{3}$ emission inventory incorporated into a climatological three-dimensional global tropospheric transport model (MOGUNTIA; Zimmermann [114]). This was a first attempt at understanding the fate of reduced nitrogen species in the atmosphere. A $10^{\circ} \times 10^{\circ} \mathrm{NH}_{3}$ emission inventory was used in this initial modeling study. Subsequently, there has been vigorous development in the modeling of $\left[\mathrm{NH}_{3}\right]$, with two approaches: Eulerian (Table 3) and Lagrangian (Table 4). The more typical implementation is the Eulerian approach (in GEOS-Chem, CMAQ, and EMEP, among others), where the properties of reference grid cells are monitored. The Lagrangian approach, which "follows" the air parcel, is applied in models such as FRAME, TREND, and STILT-CHEM.

GEOS-Chem (www.geos-chem.org) is one of the most widely used (see Table 3) three-dimensional chemical transport models (3-D CTM) in the study of $\mathrm{NH}_{3}$ in the atmosphere. Due to the environmental policies in Europe, there are several implementations for the region-TM5 [115], the EMEP model [116-118], the DAMOS/Danish Eulerian Hemispheric Model (DEHM) [119121], CHIMERE [122], MATCH [123], and LOTUS-EUROS [124]. The Community Multiscale Air Quality Modeling System (CMAQ) [125], while commonly used for air quality studies, especially over North America, is not widely [126] used to understand [ $\left.\mathrm{NH}_{3}\right]$. The Particulate Matter Comprehensive Air Quality Model with Extensions (PMCAMx) [127-129] has also been utilized for modeling $\mathrm{NH}_{3}$ over the US [130] and Europe [131]. Unlike these Eulerian CTMs, the Lagrangian approach in modeling atmospheric $\mathrm{NH}_{3}$ is used in the following: TERN [132], TREND [133,134], ACDEP [119,135-140], FRAME [141-143], NAME [144], AURAMS [145], OPS [146-148], and STILT-Chem [149] models. Some of the significant modeling studies of atmospheric $\mathrm{NH}_{3}$ using these various models are enumerated in Tables 3 and 4. The following three subsections detail the three most important processes to be considered in the modeling of $\mathrm{NH}_{3}$, viz., emission, gas-particle partitioning, and deposition. 
Table 3. Some modeling studies of atmospheric $\left[\mathrm{NH}_{3}\right]$ using Eulerian chemical transport models.

\begin{tabular}{|c|c|c|c|c|}
\hline СТМ & Equilibrium Model & Reference & Region & Period \\
\hline CHIMERE & ISORROPIA & De Meij et al. [122] & Northern Italy & 2005 \\
\hline CMAQ & MARS-A & Gilliland et al. [150] & Eastern US & 2001 \\
\hline CMAQ̄ & MARS-A & Gilliland et al. [126] & US & 2001 \\
\hline DAMOS & Frohn [151] & Brandt et al. [120] & Europe, North America & \\
\hline DAMOS & Frohn [151] & Geels et al. [121] & Denmark & 2007 \\
\hline EMEP & EQSAM & Fagerli and Aas [116] & Europe & 1990-2003 \\
\hline EMEP & EQSAM & Horvath et al. [117] & Hungary & 1990 and 1995-2004 \\
\hline \multirow[t]{10}{*}{ GEOS-Chem } & ISORROPIA II & Heald et al. [91] & US & May 2009 to April 2010 \\
\hline & ISORROPIA II & Walker et al. [152] & California & 2009 \\
\hline & RPMARES & Zhang et al. [153] & US & 2006 to 2008 \\
\hline & ISORROPIA II & Schiferl et al. [34] & California & May and Jun 2010 \\
\hline & ISORROPIA II & Paulot et al. [154] & Global oceanic & 1995-2004 \\
\hline & RPMARES & Luo et al. [100] & Global & 2007 \\
\hline & MARS-A & Zhu et al. [155] & Global and US & 2008 \\
\hline & ISORROPIA II & Schiferl et al. [156] & US & 2008-2012 \\
\hline & ISORROPIA II & Yu et al. [157] & US & 2001-2016 \\
\hline & ISORROPIA II & Nair et al. [158] & US & 2001-2017 \\
\hline \multirow[t]{2}{*}{ GEOS-Chem (adjoint) } & ISORROPIA/MARS-A & Zhu et al. [92] & US & $\begin{array}{l}\text { Apr, Jul, and Oct } \\
\text { 2006-2009 }\end{array}$ \\
\hline & RPMARES & Paulot et al. [159] & US, E.U., China & $2005-2008$ \\
\hline LOTOS-EUROS & Modified* CBM-IV & van Damme et al. [160] & Europe & 2008-2011 \\
\hline MATCH & & Langner et al. [123] & Baltic Sea Basin & 1996-2001 \\
\hline \multirow[t]{5}{*}{$\operatorname{PMCAM}_{x}$} & ISORROPIA & Pinder et al. [130] & US & $\begin{array}{l}\text { Jul and Oct 2001, Jan } \\
\text { and Apr } 2002\end{array}$ \\
\hline & & Murphy and Pandis [127] & Eastern US & Jul 2001 \\
\hline & & Tsimpidi et al. [128] & Mexico City & Apr 2003 \\
\hline & & Karydis et al. [129] & Mexico City & Apr 2003 \\
\hline & & Fountoukis et al. [131] & Europe & May 2008 \\
\hline TM5 & EQSAM & de Meij et al. [115] & Europe & 2000 \\
\hline
\end{tabular}

See Table S2 for details of Equilibrium Models. Abbreviations: CTM: Chemical Transport Model, CHIMERE: CMAQ: Community Multiscale Air Quality, DAMOS: Danish Ammonia MOdeling System, EMEP: European Monitoring and Evaluation Programme, GEOS-Chem: Goddard Earth Observing System - Chemistry, LOTOS-EUROS: LOngTerm Ozone Simulation - EURopean Operational Smog, MATCH: Multi-scale Atmospheric Transport and Chemistry, PMCAM :, TM5: Tracer Model 5. * Modification of the Carbon Bond Mechanism IV reaction mechanism with a scheme for $\mathrm{NH}_{4} \mathrm{NO}_{3}$ and $\left(\mathrm{NH}_{4}\right)_{2} \mathrm{SO}_{4}$ by Zlatev [161].

Table 4. Some modeling studies of atmospheric $\left[\mathrm{NH}_{3}\right]$ using Lagrangian chemical transport models.

\begin{tabular}{|c|c|c|c|c|}
\hline CTM & Equilibrium Model & Reference & Region & Period \\
\hline \multirow[t]{7}{*}{ ACDEP } & \multirow{7}{*}{ Modified ${ }^{*}$ CBM-IV } & Hertel et al. [135] & Denmark & 1990 \\
\hline & & Hertel et al. [119] & Baltic Sea & 1999 \\
\hline & & Gyldenkaerne et al. [136] & Northwestern Europe & 1999-2001 \\
\hline & & de Leeuw et al. [137] & North Sea & 1999 \\
\hline & & Skjøth et al. [138] & Denmark & 1998 and 1998 \\
\hline & & Skjøth et al. [139] & Denmark & 1999 to 2001 \\
\hline & & Skjøth et al. [140] & Europe & 2007 \\
\hline AURAMS & Makar et al. [162] & Makar et al. [145] & North America & 2002 \\
\hline \multirow{14}{*}{ FRAME } & \multirow{14}{*}{ Barrett et al. [163] } & Fournier et al. [164] & British Isles & 1996 \\
\hline & & Fournier et al. [165] & British Isles & 1996 \\
\hline & & Fournier et al. [166] & UK & 1996 \\
\hline & & Dore et al. [167] & UK & 2002 \\
\hline & & Sutton et al. [168] & UK & 2002-2004 \\
\hline & & Tang et al. [169] & UK & 2012 \\
\hline & & Vieno [170] & UK & 1999 \\
\hline & & Sutton et al. [171] & UK & Sep 1996 to Nov 2000 \\
\hline & & Sutton et al. [172] & UK & 1996 \\
\hline & & Hellsten et al. [173] & UK & 2000 \\
\hline & & Singles et al. [141] & Great Britain & 1987 to 1990 \\
\hline & & Hallsworth et al. [174] & UK & 2002-2004 \\
\hline & & Kryza et al. [142] & Poland & $2002-2005$ \\
\hline & & Zhang et al. [143] & North China Plain & 2008 \\
\hline \multirow{8}{*}{$\begin{array}{l}\text { NAME } \\
\text { OPS }\end{array}$} & \multirow{8}{*}{ Meng and Seinfeld [175] } & Redington and Derwent [144] & UK & 1996 \\
\hline & & van Pul et al. [176] & Netherlands & Sep 2000 to 2001 \\
\hline & & van Jaarsveld [177] & Netherlands & Jan 1998 to Dec 2000 \\
\hline & & van Pul et al. [146] & Eastern Netherlands & $2002-2003$ \\
\hline & & Stolk et al. [147] & Netherlands & $2005-2007$ \\
\hline & & van Pul et al. [146] & Netherlands & Jul 2002-Aug 2003 \\
\hline & & Kruit et al. [148] & Netherlands & 1990-2014 \\
\hline & & van der Swaluw et al. [178] & Netherlands & 1998-2002 \\
\hline \multirow{4}{*}{$\begin{array}{l}\text { STILT-Chem } \\
\text { TERN } \\
\text { TREND }\end{array}$} & \multirow[t]{4}{*}{ Wen et al. [149] } & Wen et al. [149] & Canada & Jun to Nov 2006 \\
\hline & & ApSimon et al. [132] & UK & 1983 \\
\hline & & Asman and van Jaarsveld [133] & Europe & 1990 \\
\hline & & Asman [134] & Denmark & 1996 \\
\hline
\end{tabular}

Abbreviations: CTM: Chemical Transport Model, ACDEP: Atmospheric Chemistry and DEPosition, AURAMS A Unified Regional Air quality Modeling System, FRAME: Fine Resolution AMmonia Exchange, NAME: Nuclear Accident ModEl, OPS: Operational Priority Substances, STILT-Chem: Stochastic Time-Inverted Lagrangian Transport and Chemistry, TERN: Transport over Europe of Reduced Nitrogen. ${ }^{*}$ Modification of the Carbon Bond Mechanism IV reaction mechanism with a scheme for $\mathrm{NH}_{4} \mathrm{NO}_{3}$ and $\left(\mathrm{NH}_{4}\right)_{2} \mathrm{SO}_{4}$ by Zlatev [161]. 


\subsection{Emission}

Emission inventories are required for representation in chemical transport models (CTMs), in addition to utility for assessment of air quality policies. They have been developed on scales ranging from global to regional to local for use in CTMs. Global $\mathrm{NH}_{3}$ emission inventories include the Community Emissions Data System (CEDS; Hoesly et al. [179]), the Emissions Database for Global Atmospheric Research (EDGAR; Crippa et al. [180]), the Magnitude And Seasonality of AGricultural Emissions for $\mathrm{NH}_{3}$ (MASAGE_NH $\mathrm{NH}_{3}$; Paulot et al. [159]), and the Global Emissions Inventory Activity (GEIA; Bouwman et al. [18]). Examples of regional $\mathrm{NH}_{3}$ emission inventories are the US EPA/NEI (National Emission Inventory), Canada's APEI (Air Pollutant Emissions Inventory; St-Pierre et al. [181]), EMEP (European Monitoring and Evaluation Programme) WebDab, NAEI (National Atmospheric Emission Inventory) for the UK [182], NEMA (National Emission Model for Ammonia; Velthof et al. [183]) for Netherlands, Asian MIX inventory [184], Regional Emission inventory in ASia (REAS) [185-190], and DICE-Africa (Diffuse and Inefficient Combustion Emissions in Africa; Marais and Wiedinmyer [191]). These emission inventories are detailed in Table 5 and their long-term trends are shown in Figure 3. There are inventories developed with higher spatial resolution for the Eastern United States [150], North Carolina and the San Joaquin Valley [192], and the Pearl River Delta [193] and Yangtze River Delta [194] in China.

$\mathrm{NH}_{3}$ emissions are primarily anthropogenic, coming mainly from agriculture through excreta from domestic animals and the use of synthetic fertilizers [195-201]. Approximately $60 \%$ of total $\mathrm{NH}_{3}$ emissions are from anthropogenic sources [18,202], of which $80-90 \%$ are from agricultural activity (fertilizers and livestock wastes) $[18,192,195,203]$. Other sources of $\mathrm{NH}_{3}$ include fuel combustion from vehicles and industries, biomass burning, and human wastes. Emission inventories are, therefore, generally based on emission factors from a particular source type and associated activity rate. Emission factors are based on measurement of $\mathrm{NH}_{3}$ fluxes from individual source types, such as animal houses and storage, fertilizer application, fuel combustion, biomass burning, human wastes, industries, transportation, vegetation, and soil. Activity factors indicate the potential emission from each source for specific locations based on parameters like the amount of livestock, the amount of fertilizer applied, and the amount of fuel combusted, based on the source type. The multiplicative product of the source-specific emission factor with the activity factor is the estimated spatial distribution of $\mathrm{NH}_{3}$ emissions, i.e., the emission inventory.

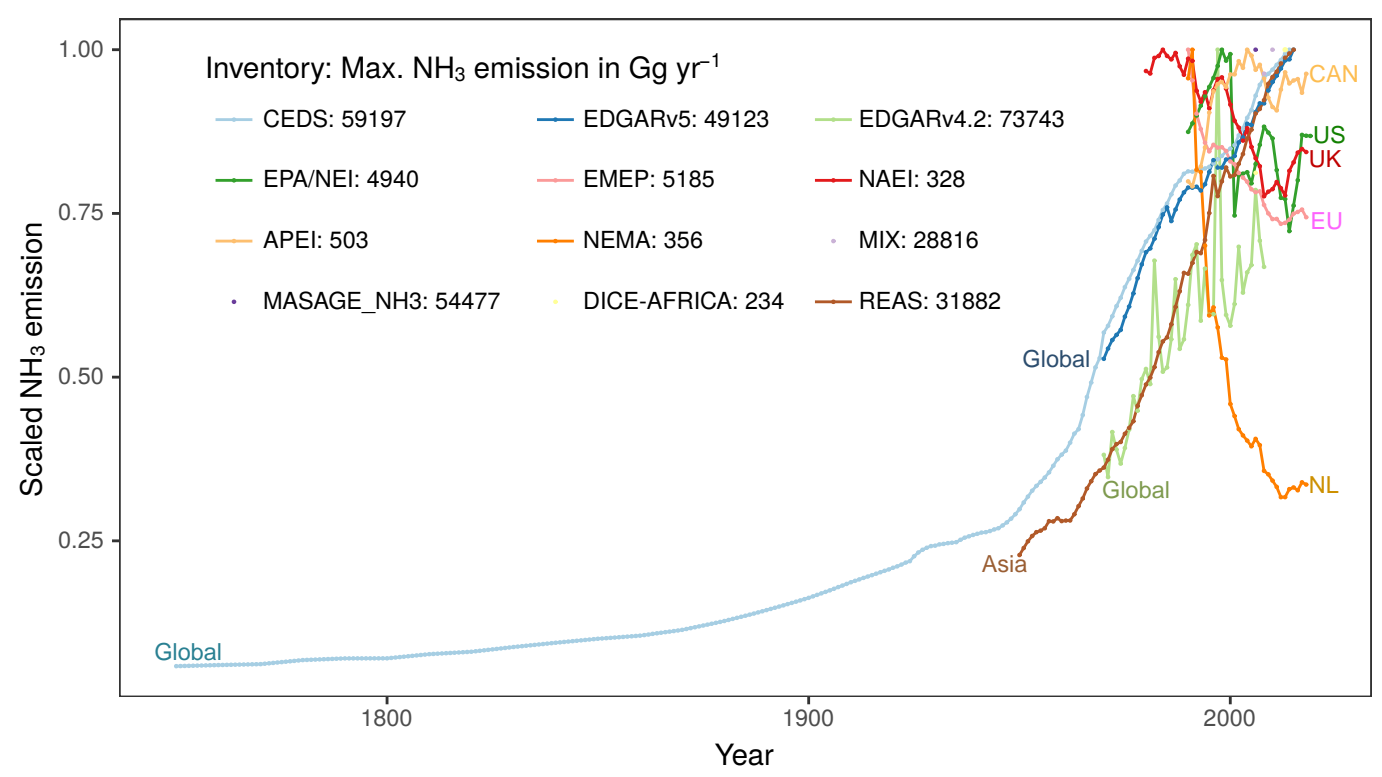

Figure 3. Time-series of annual long-term variations in ammonia emissions from multiple global and national emission inventories (listed in Table 5). The y-axis shows $\mathrm{NH}_{3}$ emissions scaled to the maximum value, which is noted in the inset legend in the units of $\mathrm{Gg} \mathrm{yr}^{-1}$. 
Table 5. Global and regional ammonia emission inventories.

\begin{tabular}{|c|c|c|c|c|}
\hline Inventory & Location & Period & Reference & Data Access \\
\hline CEDS & Global & 1750-2014 & Hoesly et al. [179] & \multirow{3}{*}{$\begin{array}{l}\text { https://github.com/JGCRI/CEDS/ } \\
\text { https:// / edgar.jrc.ec.europa.eu/overview.php?v= } \\
\text { 50_AP } \\
\text { http:/ / geoschemdata.computecanada.ca/ExtData/ } \\
\text { HEMCO/MASAGE_NH3/v2015-02/* }\end{array}$} \\
\hline EDGAR & Global & 1970-2015 & Crippa et al. [180] & \\
\hline MASAGE_NH 3 & Global & 2006 & Paulot et al. [159] & \\
\hline APEI & Canada & 1990-2018 & St-Pierre et al. [181] & \multirow{8}{*}{ 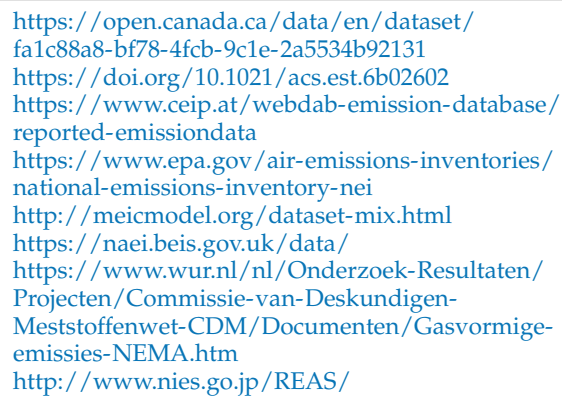 } \\
\hline DICE-Africa & Africa & 2006, 2013 & Marais and Wiedinmyer [191] & \\
\hline EMEP & EU & 1990-2018 & & \\
\hline EPA/NEI & US & 1990-2019 & & \\
\hline MIX & Asia & 2006, 2008 & Li et al. [184] & \\
\hline NAEI & & $1980-2018$ & Reis et al. [182] & \\
\hline NEMA & Netherlands & $1990-2018$ & Velthof et al. [183] & \\
\hline REAS & Asia & 1950-2015 & Kurokawa and Ohara [185] & \\
\hline
\end{tabular}

The main issues with the development of reliable $\mathrm{NH}_{3}$ emissions inventories are the dearth of emission measurements, incomplete identification of all known sources of emissions, the lack of validation with $\left[\mathrm{NH}_{3}\right]$ measurements, the variability and uncertainty of emissions estimates dependent on free ammonia concentration, differences in inventory compilation approaches due to assumptions regarding underlying emission factors and activity rates, and source significance influenced by spatial scales $[130,182,192]$. While the bottom-up approach of emissions inventory is expected to be accurate due to the detailed consideration of each source type and their emissions, it requires comprehensive information for activity factors to apply emission factors. This would require detailed measurements to capture the complex spatial variability of emissions across source types as well as temporal variability (as discussed in Section 5). Gilliland et al. [126,150] and Pinder et al. [130] observed erroneous seasonal variations in model-simulated ammonium and reduced nitrogen. Zhang et al. [153] determined that $\mathrm{NH}_{3}$ emissions (constrained and scaled by observations) are lower by a factor of 3 in winter relative to summer and are in better agreement with US network measurements of $\mathrm{NH}_{x}\left(\mathrm{NH}_{3}+\mathrm{NH}_{4}{ }^{+}\right)$and $\mathrm{NH}_{4}{ }^{+}$wet deposition fluxes. Applying modifications seemed to correct the previous observations. The underestimation of $\mathrm{NH}_{3}$ emissions in models was confirmed further by Walker et al. [152], with the additional under-prediction of $\mathrm{HNO}_{3}$ contributing to under-prediction of nitrate over California.

Recently, top-down approaches have been shown to reduce the identified issues with the accuracy of $\mathrm{NH}_{3}$ emissions inventories by using inverse modeling to relate observed $\left[\mathrm{NH}_{3}\right]$ to model emissions $[91,92,126,130,150,152,159,204]$. Although these studies have to grapple with the complexities of other model processes, comparison with bottom-up emission inventories can identify improvements in $\mathrm{NH}_{3}$ source identification and contribution. Another approach towards improving emissions inventories is using a combination of bottom-up and top-down approaches in a "hybrid" approach $[139,205]$. Regardless, current emission inventories have enabled high-resolution chemical transport models to generally capture the spatial variability of atmospheric $\mathrm{NH}_{3}$ and $\mathrm{NH}_{4}{ }^{+}$concentrations and provide a wealth of information that is currently unobtainable from direct observations, while also improving our understanding of the effects of various processes and parameters in determining $\left[\mathrm{NH}_{3}\right]$.

\subsection{Gas-Particle Partitioning}

Another significant aspect of modeling atmospheric $\left[\mathrm{NH}_{3}\right]$ is the accurate capture of phase partitioning. This is achieved through either thermodynamic equilibrium schemes or explicit mass transfer dynamical schemes. Thermodynamic equilibrium schemes generally assume aerosols to be internally mixed, i.e., all aerosol particles of a certain size range have the same composition. They 
also generally assume thermodynamic equilibrium in the gas-particle partitioning of volatile chemical species. These approaches trade off accuracy (the former) versus computational resources (the latter). Some balance can be achieved by assuming the volatile constituents being in equilibrium and shifting to mass transfer schemes when this assumption is not valid in conditions resulting in a longer chemical equilibration time as compared to the gas-aerosol diffusion timescale, typically in cooler conditions.

Over the last four decades, there has been steady development in this aspect. EQUIL was developed by Bassett and Seinfeld [206] to calculate the aerosol composition of the $\mathrm{NH}_{4}{ }^{+}-\mathrm{SO}_{4}{ }^{2-}-\mathrm{NO}_{3}{ }^{-}-\mathrm{H}_{2} \mathrm{O}$ aerosol system. KEQUIL was their [207] improvement of EQUIL with the incorporation of the Kelvin effect. Saxena et al. [29] developed the MARS scheme for the $\mathrm{SO}_{4}{ }^{2-}-\mathrm{NO}_{3}{ }^{-}-\mathrm{NH}_{4}{ }^{+}-\mathrm{H}_{2} \mathrm{O}$ system with reduced computational time through sub-domains based on $\mathrm{RH}$ and $\mathrm{NH}_{3}: \mathrm{SO}_{4}{ }^{2-}$ for aerosol species to reduce the number of equations. Further improvements were made by Binkowski and Shankar [208] and Binkowski and Roselle [209]. SEQUILIB by Pilinis and Seinfeld [210] considered $\mathrm{Na}^{+}$and $\mathrm{Cl}^{-}$, which were heretofore ignored, but are important for marine aerosols. Kim et al. [211] developed the computationally efficient gas-aerosol equilibrium model SCAPE (Simulating Composition of Atmospheric Particles at Equilibrium) without limiting assumptions. AIM [212] and AIM2 [213] approached the problem by direct minimization of the Gibbs free energy. The absence of approximations on the equilibrium concentration made AIM computationally intensive. GFEMN [214] was another iterative Gibbs free energy minimization method.

A significant step forward towards improved computational efficiency was achieved by Nenes et al. [215] with the development of ISORROPIA. ISORROPIA examines the $\mathrm{Na}^{+}-\mathrm{NH}_{4}{ }^{+}-\mathrm{Cl}^{-}-\mathrm{SO}_{4}{ }^{2-}-\mathrm{NO}_{3}{ }^{-}-\mathrm{H}_{2} \mathrm{O}$ aerosol system using pre-calculated lookup tables and a single level of iteration to make this scheme computationally efficient. This was further developed by Fountoukis and Nenes [216] into ISORROPIA II, which treats the $\mathrm{K}^{+}-\mathrm{Ca}^{2+}-\mathrm{Mg}^{2+}-\mathrm{NH}_{4}{ }^{+}-\mathrm{Na}^{+}-\mathrm{SO}_{4}{ }^{2-}-\mathrm{NO}_{3}{ }^{-}-\mathrm{Cl}^{-}-\mathrm{H}_{2} \mathrm{O}$ aerosol system, i.e., added crustals. ISORROPIA II is currently the most used thermodynamic equilibrium module within GEOS-Chem. A contrasting effort aimed at accuracy over speed is EQUISOLV [217], where direct numerical computation without simplifying assumptions was used to obtain equilibrium concentration. The three levels of nested iteration loops for higher order reactions made this computationally expensive. This was further developed into EQUISOLV II [218] with the replacement of the mass-flux iteration (MFI) method with the analytical equilibrium iteration (AEI) method for solving the set of equilibrium equations. Furthermore, the scheme was expanded to consider the potassium, calcium, magnesium, and carbonate systems. Development of thermodynamic equilibrium schemes has not been stagnant, with recent examples including HETV (HETerogeneous Vectorized) [162], MESA (Multicomponent Equilibrium Solver for Aerosols) [219], ADDEM (Aerosol Diameter DEpendent Model) [220], and UHAERO (University of Houston inorganic atmospheric AEROsol phase equilibrium model) [221]. The multicomponent equilibrium solver for aerosols (MESA) appears most interesting, with the use of a computationally efficient modified pseudo-transient continuation technique for solving the set of equilibrium reactions while maintaining overall accuracy. For a detailed review and comparison of thermodynamic equilibrium schemes, we direct you to the works of Kim et al. [211], Amundson et al. [221], Pilinis [222], Zhang et al. [223].

The assumption of equilibrium may not be justified under certain conditions, which then require explicit mass transfer dynamical schemes for gas-particle partitioning. While the equilibrium assumptions are not there to affect the accuracy of the solution, the computational cost hinders the use of these mass transfer schemes within CTMs. Development in this aspect has been limited compared to thermodynamic equilibrium schemes, with work by Meng and Seinfeld [175], Jacobson et al. [217], Jacobson [224,225], Meng et al. [226], Sun and Wexler [227], Pilinis et al. [228]. Hybrid methods have recently been developed, where the condensation or evaporation of aerosol particles with diameters of less than a threshold $(\approx 1 \mu \mathrm{m})$ are simulated using thermodynamic equilibrium schemes, and the dynamic mass-transfer approach is used for larger particles [229-232]. 


\subsection{Deposition and Bi-Directional Exchange}

Atmospheric ammonia is deposited to the surface in either the gaseous $\left(\mathrm{NH}_{3}\right)$ or aerosol $\left(\mathrm{NH}_{4}{ }^{+}\right)$ form. Unionized $\mathrm{NH}_{3}$ is mainly transferred out of the atmosphere to the surface through dry deposition $[153,233]$. Dry deposition of $\mathrm{NH}_{3}$ is faster than that of $\mathrm{NH}_{4}{ }^{+}$by a factor of $10-100$, depending on $\left[\mathrm{NH}_{3}\right.$ ], plant/terrain, and diurnal variations with meteorological conditions [234]. This leads to a short atmospheric lifetime for $\mathrm{NH}_{3}$, leading to significant deposition near its sources due to its fast deposition and higher concentration $[235,236]$.

Representation of deposition of $\mathrm{NH}_{3}$ in models is difficult due to the dearth of its measurements and because this is a complex process. Dry deposition can be typically separated into that onto soil and that onto vegetation. This process is dependent on $\left[\mathrm{NH}_{3}\right]$ above the particular surface, the equilibrium of $\left[\mathrm{NH}_{3}\right]$ over the surface determining whether emission or deposition occurs, turbulence over the surface, and extent of moisture. Studies, such as Langford and Fehsenfeld [237], show that bi-directional exchange of $\mathrm{NH}_{3}$ over vegetation is an important process, which still does not find adequate representation in models. Even this process is further complicated in that the mechanism for vegetation as a sink of $\mathrm{NH}_{3}$ could be either through cuticular or stomatal uptake [234,238]. Sutton et al. [239] identify that an accurate model representation of bi-directional exchange of $\mathrm{NH}_{3}$ is important for models to accurately quantify $\left[\mathrm{NH}_{3}\right]$, with implications for its deposition, emission, re-volatilization, and lifetime.

Although Sutton et al. [240] and Nemitz et al. [241] developed the first models for bi-directional surface-atmosphere exchanges of $\mathrm{NH}_{3}$, chemical transport models neglected to incorporate these until over a decade later. Studies [242-245] have shown better model-observation agreements resulting in more accurate quantification of $\left[\mathrm{NH}_{3}\right]$. However, some more recent studies highlight that the consideration of bi-directional exchange alone may not be sufficient. While Zhu et al. [155] implemented bidirectional exchange of $\mathrm{NH}_{3}$ into their GEOS-Chem simulations and observed improved agreement of model simulated $\left[\mathrm{NH}_{3}\right]$ with network $(\mathrm{AMoN})$ measurements, the general large underestimates (2-5 times) were not corrected, reiterating the need for an accurate representation of emissions. In contrast to the results of Heald et al. [91] for the San Joaquin valley, Zhu et al. [155] also demonstrated that adjustment to $\mathrm{HNO}_{3}$ does not significantly affect simulated $\left[\mathrm{NH}_{3}\right]$ over AMoN sites. This is consistent with the work of Park [246], which suggested that nitrate formation is $\mathrm{NH}_{3}$-limited over most of the United States. Incorporation of bi-directional exchange of $\mathrm{NH}_{3}$ did not resolve the model overestimation (3-5 times) of nitrate. Recent work by Luo et al. [247,248] shows that applying an improved wet scavenging parameterization in GEOS-Chem reduces the overestimation of nitrate and nitric acid in the model and corrects some of the deviations in atmospheric $\mathrm{NH}_{3}$ concentrations.

\subsection{Model-Observation Comparisons}

Validation of model-simulated $\left[\mathrm{NH}_{3}\right]$ with real measurements is the most important exercise not merely for the justification of model output, but for further model refinement and development. It also aids in improving our understanding of the processes controlling the concentration of ammonia in the atmosphere. A review of the literature indicates that such model-observation comparisons have been limited in spatiotemporal coverage. While there have been some comparisons of modeled $\left[\mathrm{NH}_{3}\right]$ with observations over other regions, such as Hungary [117], Denmark [121,139], and Canada [149], a majority of the more comprehensive studies have been made over the United States using the GEOS-Chem model.

Over the US, GEOS-Chem underestimation of $\left[\mathrm{NH}_{3}\right]$ was attributed to excessive $\mathrm{HNO}_{3}$ formation from $\mathrm{N}_{2} \mathrm{O}_{5}$ hydrolysis in the model by Zhang et al. [153]. the authors of Heald et al. [91] examined GEOS-Chem simulated $\left[\mathrm{NH}_{3}\right]$ with ground-based (IMPROVE) and satellite (IASI) measurements. The study demonstrated that $\mathrm{NH}_{3}$ emissions were underestimated in California and in the Midwest, which was the likely reason for the underestimation of $\mathrm{NO}_{3}{ }^{-}$formation in GEOS-Chem. This was further confirmed by Walker et al. [152] with the added possibility of $\mathrm{HNO}_{3}$ underestimation and 
topography effects on mixed-layer depths. Both studies showed that GEOS-Chem underestimated $\left[\mathrm{NH}_{3}\right]$ in comparison with satellite and in situ measurements.

Schiferl et al. [156] showed that the mean modeled $\left[\mathrm{NH}_{3}\right]$ was underestimated (2.5 ppbv vs. observed $3.4 \mathrm{ppbv}$ ) over the US during summer through a comparison with measurements from 2008 to 2012 at $11 \mathrm{AMoN}$ sites. During summer, the range in model-simulated $\left[\mathrm{NH}_{3}\right]$ was smaller, and its mean was lower (by more than $25 \%$ ) when compared to AMoN measurement data. Schiferl et al. [156] suggests that this may not be model deficiency, but that the AMoN sites' locations near high $\mathrm{NH}_{3}$ source regions causes a sampling bias due to inadequate representation of the range of $\left[\mathrm{NH}_{3}\right]$ across the US. Although modeled $\left[\mathrm{NH}_{3}\right]$ was underestimated during summer, especially near source regions (including both agricultural and fire emissions), it showed consistency in the spatiotemporal variability of $\left[\mathrm{NH}_{3}\right]$ in the column and at the surface. Inter-annual variability of modeled surface $\left[\mathrm{NH}_{3}\right]$ was lower than measurements, but the trends and variability were significant considering the fixed $\mathrm{NH}_{3}$ emissions in the model.

Paulot et al. [159] optimized simulated seasonality and magnitude of $\left[\mathrm{NH}_{3}\right]$ in the Northeast and Southwest US using the adjoint of GEOS-Chem by inversion of $\mathrm{NH}_{4}{ }^{+}$wet deposition fluxes from NADP network data for the period 2005-2008. They developed a novel bottom-up emission inventory (MASAGE_NH ${ }_{3}$ ), which simulated the magnitude and seasonality of $\left[\mathrm{NH}_{3}\right]$ in better agreement with observations in the Northeast and Southeast US, which is consistent with overestimated $\mathrm{NH}_{3}$ emissions in the US National Emissions Inventory. In the Midwest and upper Midwest, spring enhancement in $\mathrm{NH}_{3}$ was captured but not the elevated summer concentrations. Underestimation is still significant in the Atlantic and Central regions, especially in winter in the Central US.

US $\mathrm{NH}_{3}$ sources were constrained using TES satellite observations with the GEOS-Chem model and its adjoint by Zhu et al. [92]. There was an improvement in the underestimation of $\mathrm{NH}_{3}$. The range and variability improved in April and October with reduced model underestimates; however there was overestimation in July due to the constraints applied. Zhu et al. [155] tried further improvements by incorporating a bi-directional exchange (BIDI) scheme for $\mathrm{NH}_{3}$, which improves the normalized mean bias. Large underestimations (especially in October and April) still existed, which is likely due to significant errors in $\mathrm{NH}_{3}$ emission inventories.

Yu et al. [157] and Nair et al. [158] comprehensively assessed long-term (last two decades) GEOS-Chem-simulated $\left[\mathrm{NH}_{3}\right]$ over the US with empirical measurements. The strong dependence on emissions for seasonality and on acid precursor gases for long-term trends were demonstrated. Potential improvements in the representation of emissions, especially over the US Great Plains region, were identified. Furthermore, their results indicate that modeled $\left[\mathrm{NH}_{3}\right]$ is more strongly dependent on $\mathrm{NH}_{3}$ emissions than observations are. Additionally, especially over the Southeast US, considerations of changing acid precursor gas concentrations or particle acidity may need to be made in modeling $\mathrm{NH}_{3}$.

Such studies provide an examination of the role of acid precursor gases in the $\mathrm{NH}_{3}$ budget, improvement of emission parameterization, land-use and topographical considerations, evaluation of thermodynamic partitioning, and identification of other avenues for better process representation towards improved modeling of $\left[\mathrm{NH}_{3}\right]$. This is important considering the expected increasing trend of $\left[\mathrm{NH}_{3}\right]$ and its role in various atmospheric chemical processes, especially those resulting in increased aerosol loading. It should be noted that during model-observation comparisons, it is vital to also understand the limitations of observational techniques, consider nonlinearities in these comparisons (which can reveal rich information), and additionally facilitate inter-model comparisons.

\section{Spatial Distributions}

$\left[\mathrm{NH}_{3}\right]$ is predominantly controlled by emissions due to the short atmospheric lifetime of $\mathrm{NH}_{3}$. Transport, obviously, plays a role; especially that of particulate ammonium that re-volatilizes into the gas-phase $\mathrm{NH}_{3}$. The main source of $\mathrm{NH}_{3}$ emissions is agricultural land, especially in the period after chemical fertilizer application. Consequently, most $\mathrm{NH}_{3}$ hotspots are over these regions of agriculture. 
Putting together the vast literature of surface measurements of $\left[\mathrm{NH}_{3}\right]$ shows their spatial distribution and hotspots (Figure 2). Over the US, the highest surface $\left[\mathrm{NH}_{3}\right]$ are observed in the Midwest and California. This is primarily due to agriculture (including concentrated animal feeding operations) and biomass burning, respectively. Similar reasons explain the observed hotspots of $\mathrm{NH}_{3}$ over Europe and the North China Plain. The recent use of satellite remote sensing to quantify [ $\left.\mathrm{NH}_{3}\right]$ has the advantage of directly providing a global picture. Clarisse et al. [86] provided the first such global $\mathrm{NH}_{3}$ map using data from the IASI/MetOp satellite for the year 2008. Their results confirm global $\mathrm{NH}_{3}$ hotspots (total column $\mathrm{NH}_{3}>0.5 \mu \mathrm{g} \mathrm{m}^{-2}$ ) over agricultural valleys and regions of biomass burning. Using 5 years of IASI measurements, Damme et al. [102] provided a more detailed global map. Agricultural hotspots were identified over the Indo-Gangetic plain, the North China Plain, and other highly irrigated regions in Asia. Over Indonesia, there was the combined effect of intensive fertilizer application in Java and wildfires in Borneo and Sumatra. Over South America, hotspots were mainly due to biomass burning, but new agricultural hotspots over Chile and Colombia-Venezuela were revealed. Over North America, $\left[\mathrm{NH}_{3}\right]$ was elevated over the US Midwest and the San Joaquin Valley. Anthropogenic $\mathrm{NH}_{3}$ effects were seen in parts of Canada as well. Over Europe, hotspots were over the Netherlands and the Po Valley, Italy. The effect of industrial emissions was captured over South Africa. Over these hotspots, measurements would exceed total column $\mathrm{NH}_{3}$ of $3 \times 10^{16}$ molecules $\mathrm{cm}^{-2}$. Using TES data for the year 2007, Luo et al. [100] showed the enhancement of $\mathrm{NH}_{3}$ over Northern India (up to $14.45 \mathrm{ppbv} \mathrm{NH}$ in the summer) and North-Central China and spring biomass burning effects in parts of Africa and Asia. Warner et al. [89] provided a 13-year record of global $\mathrm{NH}_{3}$ distribution that confirmed the importance of agriculture and biomass burning in determining the hotspots over these regions.

Agricultural land is often mixed-use, with livestock rearing, which further contributes to $\mathrm{NH}_{3}$ emissions. Xing et al. [249] indicated that $\mathrm{NH}_{3}$ emissions from livestock activities have increased by $11 \%$ from 1990 to 2011 in the US. This could have effects on the spatial distribution of [ $\left.\mathrm{NH}_{3}\right]$. Li et al. [250] found large spatial differences in $\left[\mathrm{NH}_{3}\right]$ over the northeastern plains of Colorado, a region of concentrated agricultural activities and animal feeding operations, with mean $\mathrm{NH}_{3}$ concentrations ranging between 4 and $60 \mathrm{ppbv}$ from grasslands to feedlots with almost one hundred thousand cattle. Over the US, data from measurements and modeling $[157,158]$ indicate spatial heterogeneity based on land use. The Midwest shows the highest concentrations of $\mathrm{NH}_{3}$ due to intensive agricultural activities (including livestock rearing) as well as the energy sector. In the eastern part of the US, $\left[\mathrm{NH}_{3}\right]$ in the gas-phase is limited due to elevated $\mathrm{SO}_{2}$ and $\mathrm{NO}_{x}$ emissions from the coal-fired power plants as well as manufacturing in the Ohio River Valley region. In the western part of the US, $\left[\mathrm{NH}_{3}\right]$ is elevated over the San Joaquin Valley, possibly due to biomass burning and agriculture. Their study indicates that hotspots are highly $\mathrm{NH}_{3}$ emission-dependent and cold spots are highly $\mathrm{SO}_{2}$ and $\mathrm{NO}_{x}$ emission-dependent.

China is a large agricultural nation contributing approximately $20 \%$ of global $\mathrm{NH}_{3}$ emission $[186,188,189]$. Here, roughly $20 \%$ of the world population is fed by $10 \%$ of Earth's arable land, requiring intensive agriculture and livestock rearing. The concentrated use of fertilizers ( $30 \%$ of global usage) as well as livestock wastes contribute significantly to $\mathrm{NH}_{3}$ emissions [251,252]. Meanwhile, chemical fertilizer application in China is less efficient, resulting in a high degree of nitrogen loss $\left(\mathrm{NO}^{-}\right.$, $\mathrm{NH}_{3}, \mathrm{~N}_{2} \mathrm{O}$, and $\mathrm{N}_{2}$ ). Furthermore, about $30 \%$ of livestock products originate from the North China Plain (NCP), which further increases the $\mathrm{NH}_{3}$ emission in this highly polluted region. Over China, Liu et al. [253] used IASI satellite $\mathrm{NH}_{3} \mathrm{NH}_{3}$ retrievals and vertical $\mathrm{NH}_{3}$ profiles from MOZART to provide a comprehensive estimate of surface $\left[\mathrm{NH}_{3}\right]$ over the region. The spatial distribution of $\left[\mathrm{NH}_{3}\right]$ was as expected, aligned with intensive agricultural areas. The deviations from this distribution were explainable by concentrated animal farming locations, where livestock wastes contributed more than fertilizer use on farms. $\mathrm{NH}_{3}$ emission mitigation was not a focus for the nation until 2015, when a $\mathrm{NH}_{3}$ monitoring network (AMoN-China) was established. Using this network's data, Pan et al. [254] 
identified the $\mathrm{NCP}$ as having the highest $\left[\mathrm{NH}_{3}\right]$ followed by smaller hotspots over the Tarim basin, Chengdu Plain, and Guanzhong Plain coinciding with intensive agricultural activity.

\section{Temporal Trends}

The concentration of $\mathrm{NH}_{3}$ in the atmosphere is mainly determined by its emission. Emission is highly human activity and temperature dependent. It is expected then that the temporal trends of $\mathrm{NH}_{3}$ would be strongly correlated to those of human activity and temperature. Below we discuss the trends in $\left[\mathrm{NH}_{3}\right]$ at different temporal scales.

\subsection{Diurnal}

Diurnal variation in ambient $\left[\mathrm{NH}_{3}\right]$ has been observed to varying degrees. Variation in temperature is the primary reason for this. It may mainly affect local emissions, which are temperature-dependent and may also modulate the boundary layer depth and consequently the concentrations at the surface. Additionally, gas-particle partitioning generally peaks in the afternoon. Thus, the $\mathrm{NH}_{3}$ mixing ratios are typically at a minimum in the early morning, peak near mid-day, and decrease during the night (e.g., Langford et al. [255]). On the flip side, Alkezweeny et al. [256] were among the earliest to demonstrate lower daytime[ $\left[\mathrm{NH}_{3}\right]$, as the nighttime shows shallower boundary layer depth. Erisman et al. [257] lent further evidence of this by observing a strong decrease in $\left[\mathrm{NH}_{3}\right]$ with height, which was steeper at night likely due to temperature inversions preventing the upward transport of $\mathrm{NH}_{3}$.

Delving into this discrepancy, Buijsman et al. [258] were able to identify the expected diurnal variation occurring in low $\mathrm{NH}_{3}$ emission sites and the atypical elevated nighttime concentrations over high emission areas. The relatively lower daytime $\left[\mathrm{NH}_{3}\right]$ in high emission areas was due to higher wind speeds and more favorable mixing conditions, while at night there would be an accumulation in a the shallower boundary layer. For background stations, the opposite observations were due to the transport of $\mathrm{NH}_{3}$ from emission areas; nighttime removal of $\mathrm{NH}_{3}$ through dry deposition and conversion exceeded the transport contribution. During daytime, $\left[\mathrm{NH}_{3}\right]$ increased as atmospheric conditions permitted the vertical transport of tropospheric $\mathrm{NH}_{3}$. Additionally, the difference in $\left[\mathrm{NH}_{3}\right]$ between day and night is larger during spring and summer [259], suggesting the influence of higher emissions during warmer months. No clear diurnal profile of $\left[\mathrm{NH}_{3}\right]$ was observed in a study by Parmar et al. [260] for different seasons in an urban area with elevated [ $\left.\mathrm{NH}_{3}\right]$. Early morning decrease in $\left[\mathrm{NH}_{3}\right]$ was attributed to dew formation, which is a significant sink for soluble gases [261].

Perrino et al. [262] noted that $\mathrm{NH}_{3}$ in an urban location was much higher than at a nearby rural location and higher than an urban background station with no vehicular traffic. Additionally, the concentration and temporal trend of $\mathrm{NH}_{3}$ and $\mathrm{CO}$ were well correlated, indicating $\mathrm{NH}_{3}$ may originate from vehicular emissions and its concentration is dependent on the mixing in the atmosphere. Measurements by Ianniello et al. [263] in Beijing, China showed no observed diurnal variability for $\left[\mathrm{NH}_{3}\right]$ in both summer and winter. The highest $\left[\mathrm{NH}_{3}\right]$ were observed in the early morning during summer ( $\sim 150 \mathrm{ppbv})$ when atmospheric conditions were stable. The diurnal trends of $\left[\mathrm{NH}_{3}\right]$ were weakly dependent on air temperature and were affected by wind direction, indicating the influence of local and regional sources. $\left[\mathrm{NH}_{3}\right]$ showed a correlation with boundary layer mixing and with $\left[\mathrm{NO}_{x}\right],[\mathrm{CO}]$ and $\mathrm{PM}_{2.5}$, supporting their hypothesis that vehicular traffic may be a significant $\mathrm{NH}_{3}$ source in Beijing. Similarly, Gong et al. [264] uncovered the contribution of vehicular emissions to the morning rise in the diurnal profile of $\mathrm{NH}_{3}$ mixing ratios only in winter over urban and suburban areas of Texas, US. Notable spikes were likely due to transport from a coal power plant and some other possible sources. Large differences in $\mathrm{NH}_{3}$ diurnal profiles between weekdays weekends were likely due to higher weekday industrial activities. Road traffic was also identified by Pandolfi et al. [265] as a significant source of $\mathrm{NH}_{3}$, with a typical bimodal-traffic-driven $\mathrm{NH}_{3}$ diurnal cycle at an urban site. Significant lowering of mixing height during nighttime in an urban area may lead to higher 
measured [ $\mathrm{NH}_{3}$ ] during nighttime [266]. Some trends due to daytime increases in transportation were also observed.

Wang et al. [267] observed the diurnal profile of $\left[\mathrm{NH}_{3}\right]$ in the urban atmosphere over Shanghai, China to demonstrate a typical bimodal cycle. The two modes occurred during morning and evening traffic emissions and were modulated by atmospheric boundary layer development. On the contrary, atmospheric $\mathrm{NH}_{3}$ at a rural site showed a single mode (late morning), primarily due to volatilization from agricultural emissions as temperatures increased. In an industrial area, the diurnal profile of $\left[\mathrm{NH}_{3}\right]$ was irregular and showed no bimodal or unimodal pattern due to large industrial emission pulses, which were variable and mainly during nighttime.

As evinced by the literature reviewed, the diurnal variation in $\left[\mathrm{NH}_{3}\right]$ is not straightforward. Conventional wisdom leads to the expectation of a diurnal profile of $\mathrm{NH}_{3}$ increasing from dawn till afternoon and then decreasing due to the effect of temperature on emissions. There may be many other factors at play, such as transport, boundary layer height, deposition, fertilizer application time, traffic emissions and the interplay of all of these that result in unexpected or even opposite diurnal profiles of $\mathrm{NH}_{3}$.

\subsection{Seasonal}

The numerous studies in Table $\mathrm{S} 1$ show maximum (minimum) $\left[\mathrm{NH}_{3}\right]$ occurring during warm (cold) months. The seasonal cycle in $\left[\mathrm{NH}_{3}\right]$ is predominantly a result of the temperature dependence of: (1) gas-particle partitioning between $\mathrm{NH}_{3}$ and $\mathrm{NH}_{4}{ }^{+}$, (2) $\mathrm{NH}_{3}$ emissions from vegetation, organic wastes, and fertilizers due to Henry's law equilibrium between aqueous and gas phases $\mathrm{NH}_{3}[195,268]$, (3) turbulence, and (4) humidity [269].

Most of the listed observations show the expected maximum of gas-phase $\left[\mathrm{NH}_{3}\right]$ in the warmest summer months. Robarge et al. [270] examined the various meteorological factors that could affect $\left[\mathrm{NH}_{3}\right]$, i.e., air temperature, relative humidity, and wind speed and direction. They determined temperature to be the most significant meteorological parameter that determines $\left[\mathrm{NH}_{3}\right]$. Bari et al. [271] also demonstrated that the Manhattan summer to winter ratio was 1.5. Anatolaki and Tsitouridou [272] observed that $\left[\mathrm{NH}_{3}\right]$ were slightly higher during the warm months in Greece. Usually, this is explained by the shift of gas-particle partitioning equilibrium from $\mathrm{NH}_{4} \mathrm{NO}_{3}$ towards $\mathrm{HNO}_{3}$ and $\mathrm{NH}_{3}$ at high temperatures [273]. However, in the conditions at their measurement site, particulate $\mathrm{NH}_{4} \mathrm{NO}_{3}$ was only expected in the cold period. They suggest that photochemistry for nitric acid and local $\mathrm{NH}_{3}$ emissions from a fertilizer factory or agricultural activities could explain higher $\left[\mathrm{NH}_{3}\right]$. This is indicative of the potential of factors other than temperature, most importantly the presence of local sources, to play a role in determining the apparent seasonal variation of $\left[\mathrm{NH}_{3}\right]$.

An important non-meteorological factor is the application of fertilizers for agriculture, especially in the spring. Hoell et al. [274] were among the earliest to identify enhanced $\mathrm{NH}_{3}$ levels in March, possibly due to $\mathrm{NH}_{4} \mathrm{NO}_{3}$ volatilization from fertilizer. This springtime application of fertilizer may cause deviation from the ammonium nitrate equilibrium constant due to local sources and non-equilibrium conditions caused by high RH and the presence of sulfate acid aerosol, as observed by Cadle et al. [275].

However, Burkhardt et al. [276], noted that local sources could possibly explain the maximum seasonal arithmetic mean $\left[\mathrm{NH}_{3}\right]$ in spring and autumn, but the seasonal geometric means $\left[\mathrm{NH}_{3}\right]$ were largest in summer. Measurement of $\left[\mathrm{NH}_{3}\right]$ is generally reported as an arithmetic mean, which is affected to a higher degree by spikes associated with local sources, whereas the geometric mean is more effective at representing background $\left[\mathrm{NH}_{3}\right]$. Thus, summertime $\mathrm{NH}_{3}$ is in reality larger than spring and autumn values, where spikes associated with local agricultural emission sources appear to elevate the background $\left[\mathrm{NH}_{3}\right]$.

Alebic-Juretic [277] showed that in a residential area, within a cultivated garden, the seasonal maxima in $\left[\mathrm{NH}_{3}\right]$ are obtained during the warmer months of spring and summer. However, near industrial sources, higher $\left[\mathrm{NH}_{3}\right]$ is seen in winter and autumn. This is indicative of the role of 
the boundary layer depth in the high $\mathrm{NH}_{3}$ background in industrial source regions and the role of emissions from the green space in the lower $\mathrm{NH}_{3}$ background residential region.

These numerous studies and others listed in Table S1 demonstrate that seasonal variation of $\mathrm{NH}_{3}$ is, as expected, correlated with variation of temperature. It is most concentrated in the summer months and decreases as it gets colder. There may, however, be the effect of boundary layer height: in the winter, a lower boundary height for mixing of $\mathrm{NH}_{3}$ means more concentration. Deviations are also usually observed in spring, where it may be higher than in summer, during the period of manure and fertilizer application. The dependence on emissions also extends to the type of source. When there is a constant source of emissions, such as an industrial area, maximum $\left[\mathrm{NH}_{3}\right]$ may occur in winter due to the shallower atmospheric boundary layer. A key consideration to make is that the arithmetic seasonal mean may be greatly affected by outlier $\mathrm{NH}_{3}$ emission events, deeming the geometric mean as more representative of background concentrations.

\subsection{Long-Term Trends}

Although the effect of temperature and relative humidity is evident in the temporal trends discussed thus far, in the long term, due to the expected smoothing out of meteorological factors, long-term trends in $\mathrm{NH}_{3}$, if they exist, are mainly due to other factor(s). There have been observations of an increasing trend in $\mathrm{NH}_{3}$ levels in the atmosphere in recent years, despite almost constant or reducing emissions. It is likely that the changing chemical environment due to reducing acidic gases $\left(\mathrm{SO}_{2}\right.$ and $\left.\mathrm{NO}_{x}\right)$ means that more $\mathrm{NH}_{3}$ remains in the gas-phase with reduced available reducible species to form $\mathrm{NH}_{4}{ }^{+}$in the particle phase.

There are numerous studies (see Table S1) indicating the long-term trends in $\left[\mathrm{NH}_{3}\right]$ over North America. The concentrations of $\mathrm{NH}_{3}$ have been increasing across the US despite the nearly constant emission of $\mathrm{NH}_{3}$. Butler et al. [56] using AMoN and Yao and Zhang [278] using NAPS, CAPMoN and AMoN network data provided evidence for this increase. Analysis of satellite (AIRS)-derived $\mathrm{NH}_{3}$ retrievals [105] shows that $\left[\mathrm{NH}_{3}\right.$ ] has increased by $0.056 \pm 0.012 \mathrm{ppbv} \mathrm{yr}^{-1}\left(\approx 2.61 \% \mathrm{yr}^{-1}\right)$ over the US from 2002-2016. Ground-based measurements in Toronto, Canada showed no significant increasing trend in 2003-2011 [279] and an increasing $(\approx 20 \%)$ trend [278]; however, some sites in the US showed an increasing trend by up to $200 \%$. Over the US, Yu et al. [157] examined long-term model simulated surface $\left[\mathrm{NH}_{3}\right]$, validated with network measurements. Their observation of an increasing long-term trend of $\left[\mathrm{NH}_{3}\right]$ was demonstrated to be due to the decreasing emissions of $\mathrm{SO}_{2}$ and $\mathrm{NO}_{x}$ contributing to roughly $2 / 3$ and $1 / 3$ of its increase over the US, respectively.

In China, the burgeoning population leads to increasing demand for animal and agricultural products. To meet this demand, there has been a sharp increase in the use of fertilizers for agriculture and concentrated animal feeding operations for producing livestock. This has led to a sharp increase of $\mathrm{NH}_{3}$ emissions in China, especially in the North China Plain (NCP). A long-term record of $\mathrm{NH}_{3}$ is lacking for the nation. However, analysis of satellite (AIRS)-derived long-term $\mathrm{NH}_{3}$ retrievals [105] shows that $\mathrm{NH}_{3}$ concentrations have increased over China by $0.076 \pm 0.020 \mathrm{ppbv} \mathrm{yr}^{-1}\left(\approx 2.27 \% \mathrm{yr}^{-1}\right)$.

In the European Union, $\mathrm{NH}_{3}$ emissions fell by 23\% between 1990 and 2015 but increased between 2014 and 2015 by 1.8\%, mainly because of increases in Germany, Spain, France, and the United Kingdom. In Germany, there has been a rising trend in $\mathrm{NH}_{3}$ emissions, especially in the period since 2009. This is attributable mainly to inorganic nitrogen fertilizers. It must be noted that among the main pollutants in the $\mathrm{EU},\left[\mathrm{NH}_{3}\right]$ showed the least reduction (23\%).

One of the longest and earliest long-term records of $\left[\mathrm{NH}_{3}\right]$ measurements, determined spectrophotometrically by Nesslerization, was available in Rijeka, Croatia from 1983. Alebic-Juretic [277] examined this record for 1983-2005 and the long-term trend of gas-phase $\mathrm{NH}_{3}$ showed a weak declining trend in two sites in the vicinity of the city over the period, despite an estimated emissions reduction of $>20 \%$. Analysis of the 25-year long-term measured $\left[\mathrm{NH}_{3}\right]$ in Hungary by Horvath et al. [117] showed no decrease even in the period of large $\mathrm{NH}_{3}$ emission reduction (from 1989); in fact, a small increase was observed. Over the United Kingdom, similar observations were made 
by Tang et al. [280] for the period from September 1996 to December 2005 despite a $\approx 12 \%$ reduction in emissions during 1990 to 2004. $\mathrm{NH}_{3}$ emissions in Sweden decreased by 20.6\% during 1993-2009, and yet Ferm and Hellsten [281] observed an increase in $\left[\mathrm{NH}_{3}\right]$. The strict control on $\mathrm{NH}_{3}$ emissions in the Netherlands saw a decrease in $\left[\mathrm{NH}_{3}\right]$ for 1993-2014, but there has been a subsequent increase despite emission reduction [148]. An analysis of satellite (AIRS)-derived $\mathrm{NH}_{3}$ retrievals [105] showed that $\mathrm{NH}_{3}$ concentrations have increased over Western Europe by $0.053 \pm 0.021 \mathrm{ppbv} \mathrm{yr}^{-1}(\approx 1.83$ $\% \mathrm{yr}^{-1}$ ).

Sutton et al. [282] posited that interactions with $\mathrm{SO}_{2}$, which has shown decreasing concentrations, mask the expected decrease in $\left[\mathrm{NH}_{3}\right]$ due to slower rates of conversion from $\mathrm{NH}_{3}$ to $\mathrm{NH}_{4}{ }^{+}$leading to longer atmospheric residence time of the gaseous $\mathrm{NH}_{3}$. This is the strongest reason explaining the various observed temporal variations of $\left[\mathrm{NH}_{3}\right]$. Additionally, reduced acidic species, through an increase of cuticular resistance for $\mathrm{NH}_{3}$ uptake, can limit the potential for co-deposition (with $\mathrm{SO}_{2}$ ) and therefore reduce the dry deposition velocity, which leads to increased $\left[\mathrm{NH}_{3}\right]$. Recent examinations of measurements, remote sensing, and modeling data $[98,105,148,156,157,169,250]$ provide evidence for the effect of reducing acidic precursor gases explaining most of the observed increases in $\left[\mathrm{NH}_{3}\right]$ despite its reduced/constant emissions in certain regions.

The temporal variation in $\left[\mathrm{NH}_{3}\right]$ is therefore highly dependent on the sources of emission and its temperature dependence. Warmer periods see elevated $\left[\mathrm{NH}_{3}\right]$. Wetter periods see reduced $\left[\mathrm{NH}_{3}\right]$ due to lower temperatures and increased deposition. However, in the long term, these meteorological effects are smoothed out. Additionally, due to generally reducing emissions, there should be a negative trend in $\left[\mathrm{NH}_{3}\right]$. The studies detailed above investigated the observed opposite trend of $\mathrm{NH}_{3}$ concentration and emission and substantial evidence was presented for the significance of the changing chemical environment due to pollution-control strategies.

\section{Conclusions and Research Needs}

This paper reviewed around 540 publications dealing with the quantification of atmospheric ammonia concentrations in the atmosphere through in situ measurements, satellite remote sensing inference, and model simulations. We summarize key points in line with the aims established at the beginning of this review:

$\mathrm{NH}_{3}$ has been in the spotlight considering its increasing concentrations despite reducing emissions over most regions of the globe. It is important to examine this chemical species due to its role in $\mathrm{PM}_{2.5}$ formation, and mainly in the formation of $\mathrm{NH}_{4} \mathrm{NO}_{3}$. Its role in atmospheric new particle formation is of special interest as well. The main determinant of the concentration of ammonia in the atmosphere is its emissions. Due to the short lifetime of the gas-phase form, $\mathrm{NH}_{3}$ is concentrated over regions of intensive agriculture and concentrated animal feeding operations, such as the North China Plain, the US Midwest, the Indo-Gangetic plains, and pastoral lands of Europe. In some of these regions, $\left[\mathrm{NH}_{3}\right]$ can exceed 40 ppbv.

The variations in $\left[\mathrm{NH}_{3}\right]$ are expected to be temperature-dependent-a virtue of its strong dependence on emission. Typically, at the diurnal scale, $\left[\mathrm{NH}_{3}\right]$ varies with temperature, which is generally a function of insolation. There may be effects of vehicular emissions in pushing up $\left[\mathrm{NH}_{3}\right]$ and creating a bimodal daily cycle. However, many other factors, such as transport, boundary layer height, deposition, fertilizer application time, traffic emissions, and their interactions may result in unexpected variations of its atmospheric concentration. Seasonal and inter-annual variations are heavily meteorology dependent-warmer periods have higher $\left[\mathrm{NH}_{3}\right]$ and wetter/colder periods will have lesser $\left[\mathrm{NH}_{3}\right]$. When examining long-term trends, which have been increasing over the last several years in most regions, there is mounting evidence for the importance of the chemical environment in determining the concentration of $\mathrm{NH}_{3}$ in the atmosphere. In the long term, the effect of meteorology is generally smoothed out and these long-term trends are mainly dictated by the chemical environment. Due to stringent regulations for acid precursor gases $\left(\mathrm{SO}_{2}\right.$ and $\left.\mathrm{NO}_{x}\right)$ in most parts of the world, as well as the comparatively constant $\mathrm{NH}_{3}$ emissions, less $\mathrm{NH}_{3}$ is taken up into the particle phase. Thus, 
the concentration of $\mathrm{NH}_{3}$ is increased in the atmosphere. Sutton et al. [282] additionally suggests that dry deposition velocity is reduced due to reduced acidic precursor gases' concentrations limiting the potential for co-deposition.

The quantification of $\left[\mathrm{NH}_{3}\right]$ through in situ observations, satellite remote sensing, and modeling comes with certain caveats. The main issue with in situ measurement of $\left[\mathrm{NH}_{3}\right]$ at the surface is the high cost of comprehensive spatiotemporal coverage. $\left[\mathrm{NH}_{3}\right]$ is highly spatially variable, requiring any monitoring network to have a dense distribution of measurement stations. Online analyzers, while ideal, are not cost-effective to implement. Furthermore, there may be a non-linear negative bias in measured $\left[\mathrm{NH}_{3}\right]$ due to its stickiness (polar nature) to instrument surfaces. There is, therefore, a dearth of in situ measurements over remote areas on land, and especially over the oceans. Satellite-based instruments are currently unable to resolve this gap due to the non-optimal thermal contrasts of the oceans for inference of ammonia mixing ratios from measured spectral radiances. Satellite remote sensing approaches need to be tuned specifically for the measurement of $\left[\mathrm{NH}_{3}\right]$. Inference made from spectral radiances may be erroneous in circumstances such as nighttime and times with cloudiness. The assumed fixed vertical $\mathrm{NH}_{3}$ profile for the conversion of radiances to $\left[\mathrm{NH}_{3}\right]$ is problematic as well. There are other issues, such as the fact that most remote sensing data are not from a geostationary constellation that provides continuous global coverage. Furthermore, the spatial resolution is on the scale of several kilometers in diameter, a scale over which there can be significant variability in $\left[\mathrm{NH}_{3}\right]$. Successful modeling is highly dependent on the accurate representation of the processes discussed in Section 3. Modeling of $\left[\mathrm{NH}_{3}\right]$ in the atmosphere over oceans is non-optimal due to negligible empirical datasets for validation, uncertain marine emissions, photolysis of dissolved organic nitrogen in the surface water or in the atmosphere [154], and different chemical environments (more acidic aerosols, more fine mode particles, sea salt alkalinity) affecting partitioning. Heretofore, the ammonia concentration over oceans (pptv levels) and remote areas (low ppbv levels) was considered insignificant. New research Yu et al. [5] suggests that nucleation is enhanced in the presence of pptv levels of atmospheric $\mathrm{NH}_{3}$, making it important to understand ammonia over regions of its low concentration. Despite these issues, the three varied approaches compensate for each other's limitations to a fair degree and continue improving. A synergistic approach of measurements $\leftrightarrow$ satellite-inference $\leftrightarrow$ modeling is the current research need, which will contribute towards improved understanding of ammonia in the atmosphere.

Supplementary Materials: The following are available online at http://www.mdpi.com/2073-4433/11/10/ 1092/s1, Table S1: In situ measurements of $\left[\mathrm{NH}_{3}\right]$, Table S2: Gas-Aerosol Equilibrium Models used in Chemical Transport Models.

Funding: This research was funded by NSF grant number AGS-1550816 and NASA grant number NNX17AG35G.

Conflicts of Interest: The authors declare no conflict of interest. The funders had no role in the design of the study; in the collection, analyses, or interpretation of data; in the writing of the manuscript, or in the decision to publish the results.

\section{References}

1. Sutton, M.A.; Erisman, J.W.; Dentener, F.; Möller, D. Ammonia in the environment: From ancient times to the present. Environ. Pollut. 2008, 156, 583-604. [CrossRef]

2. Aneja, V.P.; Schlesinger, W.H.; Erisman, J.W. Effects of Agriculture upon the Air Quality and Climate: Research, Policy, and Regulations. Environ. Sci. Technol. 2009, 43, 4234-4240. [CrossRef] [PubMed]

3. Heald, C.L.; Geddes, J.A. The impact of historical land use change from 1850 to 2000 on secondary particulate matter and ozone. Atmos. Chem. Phys. 2016, 16, 14997-15010. [CrossRef]

4. Kirkby, J.; Curtius, J.; Almeida, J.; Dunne, E.; Duplissy, J.; Ehrhart, S.; Franchin, A.; Gagné, S.; Ickes, L.; Kürten, A.; et al. Role of sulphuric acid, ammonia and galactic cosmic rays in atmospheric aerosol nucleation. Nature 2011, 476, 429-433. [CrossRef] 
5. Yu, F.; Nadykto, A.B.; Herb, J.; Luo, G.; Nazarenko, K.M.; Uvarova, L.A. $\mathrm{H}_{2} \mathrm{SO}_{4}-\mathrm{H}_{2} \mathrm{O}-\mathrm{NH}_{3}$ ternary ion-mediated nucleation (TIMN): Kinetic-based model and comparison with CLOUD measurements. Atmos. Chem. Phys. 2018, 18, 17451-17474. [CrossRef]

6. Spengler, J.D.; Brauer, M.; Koutrakis, P. Acid air and health. Environ. Sci. Technol. 1990, 24, 946-956. [CrossRef]

7. Mathur, R.; Dennis, R.L. Seasonal and annual modeling of reduced nitrogen compounds over the eastern United States: Emissions, ambient levels, and deposition amounts. J. Geophys. Res. Atmos. 2003, 108. doi:10.1029/2002jd002794. [CrossRef]

8. Galloway, J.N.; Dentener, F.J.; Capone, D.G.; Boyer, E.W.; Howarth, R.W.; Seitzinger, S.P.; Asner, G.P.; Cleveland, C.C.; Green, P.; Holland, E.A.; et al. Nitrogen cycles: past, present, and future. Biogeochemistry 2004, 70, 153-226. [CrossRef]

9. Li, Y.; Schichtel, B.A.; Walker, J.T.; Schwede, D.B.; Chen, X.; Lehmann, C.M.B.; Puchalski, M.A.; Gay, D.A.; Collett, J.L. Increasing importance of deposition of reduced nitrogen in the United States. Proc. Natl. Acad. Sci. USA 2016, 113, 5874-5879. doi:10.1073/pnas.1525736113. [CrossRef] [PubMed]

10. Kharol, S.K.; Shephard, M.W.; McLinden, C.A.; Zhang, L.; Sioris, C.E.; O’Brien, J.M.; Vet, R.; Cady-Pereira, K.E.; Hare, E.; Siemons, J.; et al. Dry Deposition of Reactive Nitrogen From Satellite Observations of Ammonia and Nitrogen Dioxide Over North America. Geophys. Res. Lett. 2018, 45, 1157-1166. doi:10.1002/2017gl075832. [CrossRef]

11. Bouwman, A.F.; Vuuren, D.P.V.; Derwent, R.G.; Posch, M. A global analysis of acidification and eutrophication of terrestrial ecosystems. Water Air Soil Pollut. 2002, 141, 349-382. doi:10.1023/a:1021398008726. [CrossRef]

12. Fangmeier, A.; Hadwiger-Fangmeier, A.; der Eerden, L.V.; Jäger, H.J. Effects of atmospheric ammonia on vegetation-A review. Environ. Pollut. 1994, 86, 43-82. doi:10.1016/0269-7491(94)90008-6. [CrossRef]

13. Berman, T. Algal growth on organic compounds as nitrogen sources. J. Plankton Res. 1999, 21, $1423-1437$. doi:10.1093/plankt/21.8.1423. [CrossRef]

14. Herndon, J.; Cochlan, W.P. Nitrogen utilization by the raphidophyte Heterosigma akashiwo: Growth and uptake kinetics in laboratory cultures. Harmful Algae 2007, 6, 260-270. doi:10.1016/j.hal.2006.08.006. [CrossRef]

15. Paerl, H.W.; Scott, J.T. Throwing Fuel on the Fire: Synergistic Effects of Excessive Nitrogen Inputs and Global Warming on Harmful Algal Blooms. Environ. Sci. Technol. 2010, 44, 7756-7758. doi:10.1021/es102665e. [CrossRef] [PubMed]

16. Van Breemen, N.; Burrough, P.A.; Velthorst, E.J.; van Dobben, H.F.; de Wit, T.; Ridder, T.B.; Reijnders, H.F.R. Soil acidification from atmospheric ammonium sulphate in forest canopy throughfall. Nature 1982, 299, 548-550. doi:10.1038/299548a0. [CrossRef]

17. Galloway, J.N. Acid deposition: Perspectives in time and space. Water Air Soil Pollut. 1995, 85, 15-24. doi:10.1007/bf00483685. [CrossRef]

18. Bouwman, A.F.; Lee, D.S.; Asman, W.A.H.; Dentener, F.J.; Hoek, K.W.V.D.; Olivier, J.G.J. A global high-resolution emission inventory for ammonia. Glob. Biogeochem. Cycles 1997, 11, 561-587. doi:10.1029/97gb02266. [CrossRef]

19. Paerl, H.W. Peer Reviewed: Connecting Atmospheric Nitrogen Deposition to Coastal Eutrophication. Environ. Sci. Technol. 2002, 36, 323A-326A. doi:10.1021/es022392a. [CrossRef] [PubMed]

20. Ellis, R.A.; Jacob, D.J.; Sulprizio, M.P.; Zhang, L.; Holmes, C.D.; Schichtel, B.A.; Blett, T.; Porter, E.; Pardo, L.H.; Lynch, J.A. Present and future nitrogen deposition to national parks in the United States: critical load exceedances. Atmos. Chem. Phys. 2013, 13, 9083-9095. doi:10.5194/acp-13-9083-2013. [CrossRef]

21. Payne, R.J.; Dise, N.B.; Stevens, C.J.; Gowing, D.J.; Partners, B. Impact of nitrogen deposition at the species level. Proc. Natl. Acad. Sci. USA 2013, 110, 984-987. doi:10.1073/pnas.1214299109. [CrossRef] [PubMed]

22. Cape, J.N.; van der Eerden, L.; Fangmeier, A.; Ayres, J.; Bareham, S.; Bobbink, R.; Branquinho, C.; Crittenden, P.; Cruz, C.; Dias, T.; et al. Critical Levels for Ammonia. In Atmospheric Ammonia; Springer: Dordrecht, The Netherlands, 2009; pp. 375-382. doi:10.1007/978-1-4020-9121-6_22. [CrossRef]

23. Krupa, S.V. Effects of atmospheric ammonia (NH3) on terrestrial vegetation: a review. Environ. Pollut. 2003, 124, 179-221. doi:10.1016/s0269-7491(02)00434-7. [CrossRef]

24. Kristensen, H.H.; Wathes, C.M. Ammonia and poultry welfare: A review. World's Poult. Sci. J. 2000, 56, 235-245. doi:10.1079/wps20000018. [CrossRef] 
25. Wang, Y.M.; Meng, Q.P.; Guo, Y.M.; Wang, Y.Z.; Wang, Z.; Yao, Z.L.; Shan, T.Z. Effect of Atmospheric Ammonia on Growth Performance and Immunological Response of Broiler Chickens. J. Anim. Vet. Adv. 2010, 9, 2802-2806. doi:10.3923/javaa.2010.2802.2806. [CrossRef]

26. Seedorf, J. BMTW - Wirkung von atmosphärischem Ammoniak auf Nutztiere eine Kurzübersicht. Berl. Münch. Tierärztl. Wschr. 2013, 96-103. doi:10.2376/0005-9366-126-96. [CrossRef]

27. National Research Council. Acute Exposure Guideline Levels for Selected Airborne Chemicals; The National Academies Press: Washington, DC, USA, 2008; Volume 6. doi:10.17226/12018. [CrossRef]

28. Erisman, J.W.; Bleeker, A.; Galloway, J.; Sutton, M.S. Reduced nitrogen in ecology and the environment. Environ. Pollut. 2007, 150, 140-149. doi:10.1016/j.envpol.2007.06.033. [CrossRef]

29. Saxena, P.; Hudischewskyj, A.B.; Seigneur, C.; Seinfeld, J.H. A comparative study of equilibrium approaches to the chemical characterization of secondary aerosols. Atmos. Environ. 1986, 20, 1471-1483. doi:10.1016/0004-6981(86)90019-3. [CrossRef]

30. Baek, B.H.; Aneja, V.P.; Tong, Q. Chemical coupling between ammonia, acid gases, and fine particles. Environ. Pollut. 2004, 129, 89-98. doi:10.1016/j.envpol.2003.09.022. [CrossRef]

31. Almeida, J.; Schobesberger, S.; Kürten, A.; Ortega, I.K.; Kupiainen-Määttä, O.; Praplan, A.P.; Adamov, A.; Amorim, A.; Bianchi, F.; Breitenlechner, M.; et al. Molecular understanding of sulphuric acid-amine particle nucleation in the atmosphere. Nature 2013, 502, 359-363. doi:10.1038/nature12663. [CrossRef]

32. Racherla, P.N.; Adams, P.J. Sensitivity of global tropospheric ozone and fine particulate matter concentrations to climate change. J. Geophys. Res. 2006, 111. doi:10.1029/2005jd006939. [CrossRef]

33. Tsigaridis, K.; Krol, M.; Dentener, F.J.; Balkanski, Y.; Lathière, J.; Metzger, S.; Hauglustaine, D.A.; Kanakidou, M. Change in global aerosol composition since preindustrial times. Atmos. Chem. Phys. 2006, 6, 5143-5162. doi:10.5194/acp-6-5143-2006. [CrossRef]

34. Schiferl, L.D.; Heald, C.L.; Nowak, J.B.; Holloway, J.S.; Neuman, J.A.; Bahreini, R.; Pollack, I.B.; Ryerson, T.B.; Wiedinmyer, C.; Murphy, J.G. An investigation of ammonia and inorganic particulate matter in California during the CalNex campaign. J. Geophys. Res. Atmos. 2014, 119, 1883-1902. doi:10.1002/2013jd020765. [CrossRef]

35. D'Hondt, P. Chemkar PM10: Chemische karakterisatie van fijn stof in Vlaanderen, $2006-2007$. Technical Report D/2009/6871/015, Vlaamse Milieumaatschappij. 2009. Available online: http: / xxx.lanl.gov/abs/https:/ / www.vmm.be/publicaties/chemkar-pm10-chemische-karakterisatievan-fijn-stof-in-vlaanderen-2006-2007 (accessed on 4 August 2020).

36. Dominici, F.; Wang, Y.; Correia, A.W.; Ezzati, M.; Pope, C.A.; Dockery, D.W. Chemical Composition of Fine Particulate Matter and Life Expectancy. Epidemiology 2015, 26, 556-564. doi:10.1097/ede.0000000000000297. [CrossRef] [PubMed]

37. Döscher, A.; Gäggeler, H.W.; Schotterer, U.; Schwikowski, M. A historical record of ammonium concentrations from a glacier in the Alps. Geophys. Res. Lett. 1996, 23, 2741-2744. doi:10.1029/96g102615. [CrossRef]

38. Kang, S.; Mayewski, P.A.; Qin, D.; Yan, Y.; Zhang, D.; Hou, S.; Ren, J. Twentieth century increase of atmospheric ammonia recorded in Mount Everest ice core. J. Geophys. Res. Atmos. 2002, 107, ACL 13-1-ACL 13-9. doi:10.1029/2001jd001413. [CrossRef]

39. Kellerhals, T.; Brütsch, S.; Sigl, M.; Knüsel, S.; Gäggeler, H.W.; Schwikowski, M. Ammonium concentration in ice cores: A new proxy for regional temperature reconstruction? J. Geophys. Res. 2010, 115. doi:10.1029/2009jd012603. [CrossRef]

40. Ball, S.; Hanson, D.; Eisele, F.; McMurry, P. Laboratory studies of particle nucleation: Initial results for $\mathrm{H}_{2} \mathrm{SO}_{4}, \mathrm{H}_{2} \mathrm{O}$ and $\mathrm{NH}_{3}$ vapors. J. Geophys. Res. Atmos. 1999, 104, 23709-23718. doi:10.1029/1999JD900411. [CrossRef]

41. Benson, D.R.; Erupe, M.E.; Lee, S.H. Laboratory-measured $\mathrm{H}_{2} \mathrm{SO}_{4}-\mathrm{H}_{2} \mathrm{O}-\mathrm{NH}_{3}$ ternary homogeneous nucleation rates: Initial observations. Geophys. Res. Lett. 2009, 36, L15818. doi:10.1029/2009g1038728. [CrossRef]

42. Yu, F. Effect of ammonia on new particle formation: A kinetic $\mathrm{H}_{2} \mathrm{SO}_{4}-\mathrm{H}_{2} \mathrm{O}-\mathrm{NH}_{3}$ nucleation model constrained by laboratory measurements. J. Geophys. Res. Atmos. 2006, 111. doi:10.1029/2005jd005968. [CrossRef]

43. Wang, M.; Kong, W.; Marten, R.; He, X.C.; Chen, D.; Pfeifer, J.; Heitto, A.; Kontkanen, J.; Dada, L.; Kürten, A.; et al. Rapid growth of new atmospheric particles by nitric acid and ammonia condensation. Nature 2020, 581, 184-189. doi:10.1038/s41586-020-2270-4. [CrossRef] 
44. Boucher, O.; Randall, D.; Artaxo, P.; Bretherton, C.; Feingold, G.; Forster, P.; Kerminen, V.M.; Kondo, Y.; Liao, H.; Lohmann, U.; et al. Clouds and Aerosols. In Climate Change 2013: The Physical Science Basis. Contribution of Working Group I to the Fifth Assessment Report of the Intergovernmental Panel on Climate Change; Cambridge University Press: Cambridge, UK, 2013; pp. 571-657. doi:10.1017/cbo9781107415324.016. [CrossRef]

45. Adams, P.J.; Seinfeld, J.H.; Koch, D.M. Global concentrations of tropospheric sulfate, nitrate, and ammonium aerosol simulated in a general circulation model. J. Geophys. Res. Atmos. 1999, 104, 13791-13823. doi:10.1029/1999jd900083. [CrossRef]

46. Pye, H.O.T.; Liao, H.; Wu, S.; Mickley, L.J.; Jacob, D.J.; Henze, D.K.; Seinfeld, J.H. Effect of changes in climate and emissions on future sulfate-nitrate-ammonium aerosol levels in the United States. J. Geophys. Res. Atmos. 2009, 114. doi:10.1029/2008jd010701. [CrossRef]

47. John, H.; Seinfeld, S.N.P. Atmospheric Chemistry and Physics: From Air Pollution to Climate Change; WILEY: New York, NY, USA, 2016.

48. Shindell, D.T.; Faluvegi, G.; Koch, D.M.; Schmidt, G.A.; Unger, N.; Bauer, S.E. Improved Attribution of Climate Forcing to Emissions. Science 2009, 326, 716-718. doi:10.1126/science.1174760. [CrossRef]

49. Egner, H.; Eriksson, E. Current Data on the Chemical Composition of Air and Precipitation. Tellus 1955, 7, 266-271. doi:10.1111/j.2153-3490.1955.tb01161.x. [CrossRef]

50. Junge, C.E. Recent Investigations in Air Chemistry. Tellus 1956, 8, 127-139. doi:10.3402/tellusa.v8i2.8971. [CrossRef]

51. Appel, B.; Wall, S.; Tokiwa, Y.; Haik, M. Simultaneous nitric acid, particulate nitrate and acidity measurements in ambient air. Atmos. Environ. 1980, 14, 549-554. doi:10.1016/0004-6981(80)90084-0. [CrossRef]

52. Pio, C.A.; Nunes, T.V.; Leal, R.M. Kinetic and thermodynamic behaviour of volatile ammonium compounds in industrial and marine atmospheres. Atmos. Environ. Part A Gener. Top. 1992, 26, 505-512. doi:10.1016/0960-1686(92)90333-g. [CrossRef]

53. Ferm, M. Method for determination of atmospheric ammonia. Atmos. Environ. 1979, 13, $1385-1393$. doi:10.1016/0004-6981(79)90107-0. [CrossRef]

54. Wyers, G.; Otjes, R.; Slanina, J. A continuous-flow denuder for the measurement of ambient concentrations and surface-exchange fluxes of ammonia. Atmos. Environ. Part A Gener. Top. 1993, 27, 2085-2090. doi:10.1016/0960-1686(93)90280-c. [CrossRef]

55. Puchalski, M.A.; Sather, M.E.; Walker, J.T.; Lehmann, C.M.B.; Gay, D.A.; Mathew, J.; Robarge, W.P. Passive ammonia monitoring in the United States: Comparing three different sampling devices. J. Environ. Monit. 2011, 13, 3156. doi:10.1039/c1em10553a. [CrossRef]

56. Butler, T.; Vermeylen, F.; Lehmann, C.; Likens, G.; Puchalski, M. Increasing ammonia concentration trends in large regions of the USA derived from the NADP/AMoN network. Atmos. Environ. 2016, 146, 132-140. doi:10.1016/j.atmosenv.2016.06.033. [CrossRef]

57. Sutton, M.A.; Tang, Y.S.; Miners, B.; Fowler, D. A New Diffusion Denuder System for Long-Term, Regional Monitoring of Atmospheric Ammonia and Ammonium. Water Air Soil Pollut. Focus 2001, 1, 145-156. doi:10.1023/a:1013138601753. [CrossRef]

58. Tang, Y.S.; Cape, J.N.; Sutton, M.A. Development and Types of Passive Samplers for Monitoring Atmospheric $\mathrm{NO}_{2}$ and $\mathrm{NH}_{3}$ Concentrations. Sci. World J. 2001, 1, 513-529. doi:10.1100/tsw.2001.82. [CrossRef] [PubMed]

59. Berkhout, A.J.C.; Swart, D.P.J.; Volten, H.; Gast, L.F.L.; Haaima, M.; Verboom, H.; Stefess, G.; Hafkenscheid, T.; Hoogerbrugge, R. Replacing the AMOR with the miniDOAS in the ammonia monitoring network in the Netherlands. Atmos. Meas. Tech. 2017, 10, 4099-4120. doi:10.5194/amt-10-4099-2017. [CrossRef]

60. Lolkema, D.E.; Noordijk, H.; Stolk, A.P.; Hoogerbrugge, R.; van Zanten, M.C.; van Pul, W.A.J. The Measuring Ammonia in Nature (MAN) network in the Netherlands. Biogeosciences 2015, 12, 5133-5142. doi:10.5194/bg-12-5133-2015. [CrossRef]

61. Yao, X.; Zhang, L. Causes of Large Increases in Atmospheric Ammonia in the Last Decade across North America. ACS Omega 2019, 4, 22133-22142. doi:10.1021/acsomega.9b03284. [CrossRef]

62. Fehsenfeld, F.C. Results from an informal intercomparison of ammonia measurement techniques. J. Geophys. Res. 2002, 107. doi:10.1029/2001jd001327. [CrossRef]

63. Nowak, J.B. Chemical ionization mass spectrometry technique for detection of dimethylsulfoxide and ammonia. J. Geophys. Res. 2002, 107. doi:10.1029/2001jd001058. [CrossRef] 
64. Nowak, J.B.; Huey, L.G.; Russell, A.G.; Tian, D.; Neuman, J.A.; Orsini, D.; Sjostedt, S.J.; Sullivan, A.P.; Tanner, D.J.; Weber, R.J.; et al. Analysis of urban gas phase ammonia measurements from the 2002 Atlanta Aerosol Nucleation and Real-Time Characterization Experiment (ANARChE). J. Geophys. Res. 2006, 111. doi:10.1029/2006jd007113. [CrossRef]

65. Nowak, J.B.; Neuman, J.A.; Kozai, K.; Huey, L.G.; Tanner, D.J.; Holloway, J.S.; Ryerson, T.B.; Frost, G.J.; McKeen, S.A.; Fehsenfeld, F.C. A chemical ionization mass spectrometry technique for airborne measurements of ammonia. J. Geophys. Res. Atmos. 2007, 112. doi:10.1029/2006jd007589. [CrossRef]

66. Norman, M.; Hansel, A.; Wisthaler, A. $\mathrm{O}^{2+}$ as reagent ion in the PTR-MS instrument: Detection of gas-phase ammonia. Int. J. Mass Spectrom. 2007, 265, 382-387. doi:10.1016/j.ijms.2007.06.010. [CrossRef]

67. Norman, M.; Spirig, C.; Wolff, V.; Trebs, I.; Flechard, C.; Wisthaler, A.; Schnitzhofer, R.; Hansel, A.; Neftel, A. Intercomparison of ammonia measurement techniques at an intensively managed grassland site (Oensingen, Switzerland). Atmos. Chem. Phys. 2009, 9, 2635-2645. doi:10.5194/acp-9-2635-2009. [CrossRef]

68. Von Bobrutzki, K.; Braban, C.F.; Famulari, D.; Jones, S.K.; Blackall, T.; Smith, T.E.L.; Blom, M.; Coe, H.; Gallagher, M.; Ghalaieny, M.; et al. Field inter-comparison of eleven atmospheric ammonia measurement techniques. Atmos. Meas. Tech. 2010, 3, 91-112. doi:10.5194/amt-3-91-2010. [CrossRef]

69. Ellis, R.A.; Murphy, J.G.; Pattey, E.; van Haarlem, R.; O’Brien, J.M.; Herndon, S.C. Characterizing a Quantum Cascade Tunable Infrared Laser Differential Absorption Spectrometer (QC-TILDAS) for measurements of atmospheric ammonia. Atmos. Meas. Tech. 2010, 3, 397-406. doi:10.5194/amt-3-397-2010. [CrossRef]

70. Edner, H.; Amer, R.; Ragnarsson, P.; Rudin, M.; Svanberg, S. Atmospheric $\mathrm{NH}_{3}$ monitoring by long-path UV absorption spectroscopy. In Proceedings of the Environment and Pollution Measurement Sensors and Systems; Nielsen, H.O., Ed.; SPIE: Bellingham, WA, USA, 1990; pp. 14-20. doi:10.1117/12.20339. [CrossRef]

71. Gall, R.; Perner, D.; Ladstätter-Weißenmayer, A. Simultaneous determination of $\mathrm{NH}_{3}, \mathrm{SO}_{2}, \mathrm{NO}_{\text {and }} \mathrm{NO}_{2}$ by direct UV-absorption in ambient air. Fresenius J. Anal. Chem. 1991, 340, 646-649. doi:10.1007/bf00321528. [CrossRef]

72. Edner, H.; Ragnarson, P.; Spännare, S.; Svanberg, S. Differential optical absorption spectroscopy (DOAS) system for urban atmospheric pollution monitoring. Appl. Opt. 1993, 32, 327. doi:10.1364/ao.32.000327. [CrossRef] [PubMed]

73. Mount, G.H.; Rumburg, B.; Havig, J.; Lamb, B.; Westberg, H.; Yonge, D.; Johnson, K.; Kincaid, R. Measurement of atmospheric ammonia at a dairy using differential optical absorption spectroscopy in the mid-ultraviolet. Atmos. Environ. 2002, 36, 1799-1810. doi:10.1016/s1352-2310(02)00158-9. [CrossRef]

74. Neftel, A.; Blatter, A.; Staffelbach, T. Gas phase measurements of NH3and NH4 \pm with Differential Optical Absorption Spectroscopy and Gas Stripping Scrubber in combination with Flow Injection Analysis. In Physico-Chemical Behaviour of Atmospheric Pollutants; Springer: Dordrecht, The Netherlands, 1990; pp. 83-91. doi:10.1007/978-94-009-0567-2_13. [CrossRef]

75. Mennen, M.; Elzakker, B.V.; Putten, E.V.; Uiterwijk, J.; Regts, T.; Hellemond, J.V.; Wyers, G.; Otjes, R.; Verhage, A.; Wouters, L.; et al. Evaluation of automatic ammonia monitors for application in an air quality monitoring network. Atmos. Environ. 1996, 30, 3239-3256. doi:10.1016/1352-2310(96)00079-9. [CrossRef]

76. Volten, H.; Bergwerff, J.B.; Haaima, M.; Lolkema, D.E.; Berkhout, A.J.C.; van der Hoff, G.R.; Potma, C.J.M.; Kruit, R.J.W.; van Pul, W.A.J.; Swart, D.P.J. Two instruments based on differential optical absorption spectroscopy (DOAS) to measure accurate ammonia concentrations in the atmosphere. Atmos. Meas. Tech. 2012, 5, 413-427. doi:10.5194/amt-5-413-2012. [CrossRef]

77. Sintermann, J.; Dietrich, K.; Häni, C.; Bell, M.; Jocher, M.; Neftel, A. A miniDOAS instrument optimised for ammonia field measurements. Atmos. Meas. Tech. 2016, 9, 2721-2734. doi:10.5194/amt-9-2721-2016. [CrossRef]

78. Ten Brink, H.; Otjes, R.; Jongejan, P.; Slanina, S. An instrument for semi-continuous monitoring of the size-distribution of nitrate, ammonium, sulphate and chloride in aerosol. Atmos. Environ. 2007, 41, 2768-2779. doi:10.1016/j.atmosenv.2006.11.041. [CrossRef]

79. Rumsey, I.C.; Cowen, K.A.; Walker, J.T.; Kelly, T.J.; Hanft, E.A.; Mishoe, K.; Rogers, C.; Proost, R.; Beachley, G.M.; Lear, G.; et al. An assessment of the performance of the Monitor for AeRosols and GAses in ambient air (MARGA): a semi-continuous method for soluble compounds. Atmos. Chem. Phys. 2014, 14, 5639-5658. doi:10.5194/acp-14-5639-2014. [CrossRef] 
80. Schwab, J.J.; Li, Y.; Bae, M.S.; Demerjian, K.L.; Hou, J.; Zhou, X.; Jensen, B.; Pryor, S.C. A Laboratory Intercomparison of Real-Time Gaseous Ammonia Measurement Methods. Environ. Sci. Technol. 2007, 41, 8412-8419. doi:10.1021/es070354r. [CrossRef]

81. Erisman, J. Instrument development and application in studies and monitoring of ambient ammonia. Atmos. Environ. 2001, 35, 1913-1922. doi:10.1016/s1352-2310(00)00544-6. [CrossRef]

82. Harrison, R.M.; Allen, A. Measurements of atmospheric $\mathrm{HNO}_{3}, \mathrm{HCl}$ and associated species on a small network in eastern England. Atmos. Environ. Part A Gener. Top. 1990, 24, 369-376. doi:10.1016/0960-1686(90)90116-5. [CrossRef]

83. Simmons, J.W.; Gordy, W. Structure of the Inversion Spectrum of Ammonia. Phys. Rev. 1948, 73, 713-718. doi:10.1103/PhysRev.73.713. [CrossRef]

84. Beer, R.; Shephard, M.W.; Kulawik, S.S.; Clough, S.A.; Eldering, A.; Bowman, K.W.; Sander, S.P.; Fisher, B.M.; Payne, V.H.; Luo, M.; et al. First satellite observations of lower tropospheric ammonia and methanol. Geophys. Res. Lett. 2008, 35. doi:10.1029/2008g1033642. [CrossRef]

85. Rodgers, C.D.; Connor, B.J. Intercomparison of remote sounding instruments. J. Geophys. Res. Atmos. 2003, 108, n/a-n/a. doi:10.1029/2002jd002299. [CrossRef]

86. Clarisse, L.; Clerbaux, C.; Dentener, F.; Hurtmans, D.; Coheur, P.F. Global ammonia distribution derived from infrared satellite observations. Nat. Geosci. 2009, 2, 479-483. doi:10.1038/ngeo551. [CrossRef]

87. Pinder, R.W.; Walker, J.T.; Bash, J.O.; Cady-Pereira, K.E.; Henze, D.K.; Luo, M.; Osterman, G.B.; Shephard, M.W. Quantifying spatial and seasonal variability in atmospheric ammonia with in situ and space-based observations. Geophys. Res. Lett. 2011, 38, L04802. doi:10.1029/2010g1046146. [CrossRef]

88. Shephard, M.W.; Cady-Pereira, K.E. Cross-track Infrared Sounder (CrIS) satellite observations of tropospheric ammonia. Atmos. Meas. Tech. 2015, 8, 1323-1336. doi:10.5194/amt-8-1323-2015. [CrossRef]

89. Warner, J.X.; Wei, Z.; Strow, L.L.; Dickerson, R.R.; Nowak, J.B. The global tropospheric ammonia distribution as seen in the 13-year AIRS measurement record. Atmos. Chem. Phys. 2016, 16, 5467-5479. doi:10.5194/acp-16-5467-2016. [CrossRef]

90. Someya, Y.; Imasu, R.; Shiomi, K.; Saitoh, N. Atmospheric ammonia retrieval from the TANSO-FTS/GOSAT thermal infrared sounder. Atmos. Meas. Tech. 2020, 13, 309-321. doi:10.5194/amt-13-309-2020. [CrossRef]

91. Heald, C.L.; Collett, J.L., Jr.; Lee, T.; Benedict, K.B.; Schwandner, F.M.; Li, Y.; Clarisse, L.; Hurtmans, D.R.; Damme, M.V.; Clerbaux, C.; et al. Atmospheric ammonia and particulate inorganic nitrogen over the United States. Atmos. Chem. Phys. 2012, 12, 10295-10312. doi:10.5194/acp-12-10295-2012. [CrossRef]

92. Zhu, L.; Henze, D.K.; Cady-Pereira, K.E.; Shephard, M.W.; Luo, M.; Pinder, R.W.; Bash, J.O.; Jeong, G.R. Constraining U.S. ammonia emissions using TES remote sensing observations and the GEOS-Chem adjoint model. J. Geophys. Res. Atmos. 2013, 118, 3355-3368. doi:10.1002/jgrd.50166. [CrossRef]

93. Coheur, P.F.; Clarisse, L.; Turquety, S.; Hurtmans, D.; Clerbaux, C. IASI measurements of reactive trace species in biomass burning plumes. Atmos. Chem. Phys. 2009, 9, 5655-5667. doi:10.5194/acp-9-5655-2009. [CrossRef]

94. Clerbaux, C.; Boynard, A.; Clarisse, L.; George, M.; Hadji-Lazaro, J.; Herbin, H.; Hurtmans, D.; Pommier, M.; Razavi, A.; Turquety, S.; et al. Monitoring of atmospheric composition using the thermal infrared IASI/MetOp sounder. Atmos. Chem. Phys. 2009, 9, 6041-6054. doi:10.5194/acp-9-6041-2009. [CrossRef]

95. Clarisse, L.; Shephard, M.W.; Dentener, F.; Hurtmans, D.; Cady-Pereira, K.; Karagulian, F.; Damme, M.V.; Clerbaux, C.; Coheur, P.F. Satellite monitoring of ammonia: A case study of the San Joaquin Valley. J. Geophys. Res. 2010, 115. doi:10.1029/2009jd013291. [CrossRef]

96. Ginoux, P.; Clarisse, L.; Clerbaux, C.; Coheur, P.F.; Dubovik, O.; Hsu, N.C.; Damme, M.V. Mixing of dust and $\mathrm{NH}_{3}$ observed globally over anthropogenic dust sources. Atmos. Chem. Phys. 2012, 12, 7351-7363. doi:10.5194/acp-12-7351-2012. [CrossRef]

97. R'Honi, Y.; Clarisse, L.; Clerbaux, C.; Hurtmans, D.; Duflot, V.; Turquety, S.; Ngadi, Y.; Coheur, P.F. Exceptional emissions of $\mathrm{NH}_{3}$ and $\mathrm{HCOOH}$ in the 2010 Russian wildfires. Atmos. Chem. Phys. 2013, 13, 4171-4181. doi:10.5194/acp-13-4171-2013. [CrossRef]

98. Van Damme, M.; Wichink Kruit, R.J.; Schaap, M.; Clarisse, L.; Clerbaux, C.; Coheur, P.F.; Dammers, E.; Dolman, A.J.; Erisman, J.W. Evaluating 4 years of atmospheric ammonia $\left(\mathrm{NH}_{3}\right)$ over Europe using IASI satellite observations and LOTOS-EUROS model results. J. Geophys. Res. Atmos. 2014, 119, 9549-9566. doi:10.1002/2014JD021911. [CrossRef] 
99. Sun, K.; Cady-Pereira, K.; Miller, D.J.; Tao, L.; Zondlo, M.A.; Nowak, J.B.; Neuman, J.A.; Mikoviny, T.; Müller, M.; Wisthaler, A.; et al. Validation of TES ammonia observations at the single pixel scale in the San Joaquin Valley during DISCOVER-AQ. J. Geophys. Res. Atmos. 2015, 120, 5140-5154. doi:10.1002/2014jd022846. [CrossRef]

100. Luo, M.; Shephard, M.W.; Cady-Pereira, K.E.; Henze, D.K.; Zhu, L.; Bash, J.O.; Pinder, R.W.; Capps, S.L.; Walker, J.T.; Jones, M.R. Satellite observations of tropospheric ammonia and carbon monoxide: Global distributions, regional correlations and comparisons to model simulations. Atmos. Environ. 2015, 106, 262-277. doi:10.1016/j.atmosenv.2015.02.007. [CrossRef]

101. Shephard, M.W.; McLinden, C.A.; Cady-Pereira, K.E.; Luo, M.; Moussa, S.G.; Leithead, A.; Liggio, J.; Staebler, R.M.; Akingunola, A.; Makar, P.; et al. Tropospheric Emission Spectrometer (TES) satellite observations of ammonia, methanol, formic acid, and carbon monoxide over the Canadian oil sands: validation and model evaluation. Atmos. Meas. Tech. 2015, 8, 5189-5211. doi:10.5194/amt-8-5189-2015. [CrossRef]

102. Damme, M.V.; Erisman, J.W.; Clarisse, L.; Dammers, E.; Whitburn, S.; Clerbaux, C.; Dolman, A.J.; Coheur, P.F. Worldwide spatiotemporal atmospheric ammonia $\left(\mathrm{NH}_{3}\right)$ columns variability revealed by satellite. Geophys. Res. Lett. 2015, 42, 8660-8668. doi:10.1002/2015g1065496. [CrossRef]

103. Dammers, E.; Palm, M.; Van Damme, M.; Vigouroux, C.; Smale, D.; Conway, S.; Toon, G.C.; Jones, N.; Nussbaumer, E.; Warneke, T.; et al. An evaluation of IASI-NH 3 with ground-based Fourier transform infrared spectroscopy measurements. Atmos. Chem. Phys. 2016, 16, 10351-10368. doi:10.5194/acp-16-10351-2016. [CrossRef]

104. Höpfner, M.; Volkamer, R.; Grabowski, U.; Grutter, M.; Orphal, J.; Stiller, G.; von Clarmann, T.; Wetzel, G. First detection of ammonia $\left(\mathrm{NH}_{3}\right)$ in the Asian summer monsoon upper troposphere. Atmos. Chem. Phys. 2016, 16, 14357-14369. doi:10.5194/acp-16-14357-2016. [CrossRef]

105. Warner, J.X.; Dickerson, R.R.; Wei, Z.; Strow, L.L.; Wang, Y.; Liang, Q. Increased atmospheric ammonia over the world's major agricultural areas detected from space. Geophys. Res. Lett. 2017, 44, 2875-2884. doi:10.1002/2016GL072305. [CrossRef]

106. Bray, C.D.; Battye, W.; Aneja, V.P.; Tong, D.; Lee, P.; Tang, Y.; Nowak, J.B. Evaluating ammonia $\left(\mathrm{NH}_{3}\right)$ predictions in the NOAA National Air Quality Forecast Capability (NAQFC) using in-situ aircraft and satellite measurements from the CalNex2010 campaign. Atmos. Environ. 2017, 163, 65-76. doi:10.1016/j.atmosenv.2017.05.032. [CrossRef]

107. Hickman, J.E.; Dammers, E.; Galy-Lacaux, C.; van der Werf, G.R. Satellite evidence of substantial rain-induced soil emissions of ammonia across the Sahel. Atmos. Chem. Phys. 2018, 18, 16713-16727. doi:10.5194/acp-18-16713-2018. [CrossRef]

108. Damme, M.V.; Clarisse, L.; Whitburn, S.; Hadji-Lazaro, J.; Hurtmans, D.; Clerbaux, C.; Coheur, P.F. Industrial and agricultural ammonia point sources exposed. Nature 2018, 564, 99-103. doi:10.1038/s41586-018-0747-1. [CrossRef] [PubMed]

109. Adams, C.; McLinden, C.A.; Shephard, M.W.; Dickson, N.; Dammers, E.; Chen, J.; Makar, P.; Cady-Pereira, K.E.; Tam, N.; Kharol, S.K.; et al. Satellite-derived emissions of carbon monoxide, ammonia, and nitrogen dioxide from the 2016 Horse River wildfire in the Fort McMurray area. Atmos. Chem. Phys. 2019, 19, 2577-2599. doi:10.5194/acp-19-2577-2019. [CrossRef]

110. Clarisse, L.; Damme, M.V.; Gardner, W.; Coheur, P.F.; Clerbaux, C.; Whitburn, S.; Hadji-Lazaro, J.; Hurtmans, D. Atmospheric ammonia $\left(\mathrm{NH}_{3}\right)$ emanations from Lake Natron's saline mudflats. Sci. Rep. $2019,9$. doi:10.1038/s41598-019-39935-3. [CrossRef] [PubMed]

111. Clarisse, L.; Van Damme, M.; Clerbaux, C.; Coheur, P.F. Tracking down global $\mathrm{NH}_{3}$ point sources with wind-adjusted superresolution. Atmos. Meas. Tech. 2019, 12, 5457-5473. doi:10.5194/amt-12-5457-2019. [CrossRef]

112. Shephard, M.W.; Dammers, E.; Cady-Pereira, K.E.; Kharol, S.K.; Thompson, J.; Gainariu-Matz, Y.; Zhang, J.; McLinden, C.A.; Kovachik, A.; Moran, M.; et al. Ammonia measurements from space with the Cross-track Infrared Sounder: characteristics and applications. Atmos. Chem. Phys. 2020, 20, 2277-2302. doi:10.5194/acp-20-2277-2020. [CrossRef]

113. Dentener, F.J.; Crutzen, P.J. A three-dimensional model of the global ammonia cycle. J. Atmos. Chem. 1994, 19, 331-369. doi:10.1007/bf00694492. [CrossRef]

114. Zimmermann, P.H. MOGUNTIA: A handy global tracer model. In Air Pollution Modelling and Its Applications VI; van Dop, H., Ed.; Plenum: New York, NY, USA, 1988; pp. 593-608. 
115. De Meij, A.; Krol, M.; Dentener, F.; Vignati, E.; Cuvelier, C.; Thunis, P. The sensitivity of aerosol in Europe to two different emission inventories and temporal distribution of emissions. Atmos. Chem. Phys. 2006, 6, 4287-4309. doi:10.5194/acp-6-4287-2006. [CrossRef]

116. Fagerli, H.; Aas, W. Trends of nitrogen in air and precipitation: Model results and observations at EMEP sites in Europe, 1980-2003. Environ. Pollut. 2008, 154, 448-461. doi:10.1016/j.envpol.2008.01.024. [CrossRef]

117. Horvath, L.; Fagerli, H.; Sutton, M.A. Long-Term Record (1981-2005) of Ammonia and Ammonium Concentrations. In Atmospheric Ammonia; Springer: Berlin/Heidelberg, Germany, 2009; pp. 181-185. doi:10.1007/978-1-4020-9121-6_12. [CrossRef]

118. Simpson, D.; Benedictow, A.; Berge, H.; Bergström, R.; Emberson, L.D.; Fagerli, H.; Flechard, C.R.; Hayman, G.D.; Gauss, M.; Jonson, J.E.; et al. The EMEP MSC-W chemical transport model \&ndash; technical description. Atmos. Chem. Phys. 2012, 12, 7825-7865. doi:10.5194/acp-12-7825-2012. [CrossRef]

119. Hertel, O.; Ambelas Skjøth, C.; Brandt, J.; Christensen, J.H.; Frohn, L.M.; Frydendall, J. Operational mapping of atmospheric nitrogen deposition to the Baltic Sea. Atmos. Chem. Phys. 2003, 3, 2083-2099. doi:10.5194/acp-3-2083-2003. [CrossRef]

120. Brandt, J.; Silver, J.D.; Frohn, L.; Geels, C.; Gross, A.; Hansen, A.B.; Hansen, K.M.; Hedegaard, G.B.; Skjøth, C.A.; Villadsen, H.; et al. An integrated model study for Europe and North America using the Danish Eulerian Hemispheric Model with focus on intercontinental transport of air pollution. Atmos. Environ. 2012, 53, 156-176. doi:10.1016/j.atmosenv.2012.01.011. [CrossRef]

121. Geels, C.; Andersen, H.V.; Skjøth, C.A.; Christensen, J.H.; Ellermann, T.; Løfstrøm, P.; Gyldenkærne, S.; Brandt, J.; Hansen, K.M.; Frohn, L.M.; et al. Improved modelling of atmospheric ammonia over Denmark using the coupled modelling system DAMOS. Biogeosciences 2012, 9, 2625-2647. doi:10.5194/bg-9-2625-2012. [CrossRef]

122. De Meij, A.; Thunis, P.; Bessagnet, B.; Cuvelier, C. The sensitivity of the CHIMERE model to emissions reduction scenarios on air quality in Northern Italy. Atmos. Environ. 2009, 43, 1897-1907. doi:10.1016/j.atmosenv.2008.12.036. [CrossRef]

123. Langner, J.; Andersson, C.; Engardt, M. Atmospheric input of nitrogen to the Baltic Sea basin: present situation, variability due to meteorology and impact of climate change. Boreal Environ. Res. 2009, 14, $226-237$.

124. Barbu, A.; Segers, A.; Schaap, M.; Heemink, A.; Builtjes, P. A multi-component data assimilation experiment directed to sulphur dioxide and sulphate over Europe. Atmos. Environ. 2009, 43, 1622-1631. doi:10.1016/j.atmosenv.2008.12.005. [CrossRef]

125. Byun, D.; Schere, K.L. Review of the Governing Equations, Computational Algorithms, and Other Components of the Models-3 Community Multiscale Air Quality (CMAQ) Modeling System. Appl. Mech. Rev. 2006, 59, 51. doi:10.1115/1.2128636. [CrossRef]

126. Gilliland, A.B.; Appel, K.W.; Pinder, R.W.; Dennis, R.L. Seasonal $\mathrm{NH}_{3}$ emissions for the continental united states: Inverse model estimation and evaluation. Atmos. Environ. 2006, 40, 4986-4998. doi:10.1016/j.atmosenv.2005.12.066. [CrossRef]

127. Murphy, B.N.; Pandis, S.N. Simulating the Formation of Semivolatile Primary and Secondary Organic Aerosol in a Regional Chemical Transport Model. Environ. Sci. Technol. 2009, 43, 4722-4728. doi:10.1021/es803168a. [CrossRef]

128. Tsimpidi, A.P.; Karydis, V.A.; Zavala, M.; Lei, W.; Molina, L.; Ulbrich, I.M.; Jimenez, J.L.; Pandis, S.N. Evaluation of the volatility basis-set approach for the simulation of organic aerosol formation in the Mexico City metropolitan area. Atmos. Chem. Phys. 2010, 10, 525-546. doi:10.5194/acp-10-525-2010. [CrossRef]

129. Karydis, V.A.; Tsimpidi, A.P.; Fountoukis, C.; Nenes, A.; Zavala, M.; Lei, W.; Molina, L.T.; Pandis, S.N. Simulating the fine and coarse inorganic particulate matter concentrations in a polluted megacity. Atmos. Environ. 2010, 44, 608-620. doi:10.1016/j.atmosenv.2009.11.023. [CrossRef]

130. Pinder, R.W.; Adams, P.J.; Pandis, S.N.; Gilliland, A.B. Temporally resolved ammonia emission inventories: Current estimates, evaluation tools, and measurement needs. J. Geophys. Res. 2006, 111. doi:10.1029/2005jd006603. [CrossRef]

131. Fountoukis, C.; Racherla, P.N.; van der Gon, H.A.C.D.; Polymeneas, P.; Charalampidis, P.E.; Pilinis, C.; Wiedensohler, A.; Dall'Osto, M.; O'Dowd, C.; Pandis, S.N. Evaluation of a three-dimensional chemical transport model (PMCAMx) in the European domain during the EUCAARI May 2008 campaign. Atmos. Chem. Phys. 2011, 11, 10331-10347. doi:10.5194/acp-11-10331-2011. [CrossRef] 
132. ApSimon, H.; Barker, B.; Kayin, S. Modelling studies of the atmospheric release and transport of ammonia in anticyclonic episodes. Atmos. Environ. 1994, 28, 665-678. doi:10.1016/1352-2310(94)90043-4. [CrossRef]

133. Asman, W.A.; van Jaarsveld, H.A. A variable-resolution transport model applied for NHx in Europe. Atmos. Environ. Part A Gener. Top. 1992, 26, 445-464. doi:10.1016/0960-1686(92)90329-j. [CrossRef]

134. Asman, W. Modelling the atmospheric transport and deposition of ammonia and ammonium: an overview with special reference to Denmark. Atmos. Environ. 2001, 35, 1969-1983. doi:10.1016/s1352-2310(00)00548-3. [CrossRef]

135. Hertel, O.; Christensen, J.; Runge, E.H.; Asman, W.A.; Berkowicz, R.; Hovmand, M.F.; Hov, Ø. Development and testing of a new variable scale air pollution model- ACDEP. Atmos. Environ. 1995, 29, 1267-1290. doi:10.1016/1352-2310(95)00067-9. [CrossRef]

136. Gyldenkaerne, S.; Ambelas Skjøth, C.; Hertel, O.; Ellermann, T. A dynamical ammonia emission parameterization for use in air pollution models. J. Geophys. Res. Atmos. 2005, 110. doi:10.1029/2004JD005459. [CrossRef]

137. De Leeuw, G.; Spokes, L.; Jickells, T.; Skjøth, C.A.; Hertel, O.; Vignati, E.; Tamm, S.; Schulz, M.; Sørensen, L.L.; Pedersen, B.; et al. Atmospheric nitrogen inputs into the North Sea: effect on productivity. Cont. Shelf Res. 2003, 23, 1743-1755. doi:10.1016/j.csr.2003.06.011. [CrossRef]

138. Skjøth, C.A.; Hertel, O.; Ellermann, T. Use of the ACDEP trajectory model in the Danish nation-wide Background Monitoring Programme. Phys. Chem. Earth Parts A/B/C 2002, 27, 1469-1477. doi:10.1016/S1474-7065(02)00149-3. [CrossRef]

139. Skjøth, C.A.; Hertel, O.; Gyldenkaerne, S.; Ellermann, T. Implementing a dynamical ammonia emission parameterization in the large-scale air pollution model ACDEP. J. Geophys. Res. Atmos. 2004, 109. doi:10.1029/2003JD003895. [CrossRef]

140. Skjøth, C.A.; Geels, C.; Berge, H.; Gyldenkærne, S.; Fagerli, H.; Ellermann, T.; Frohn, L.M.; Christensen, J.; Hansen, K.M.; Hansen, K.; et al. Spatial and temporal variations in ammonia emissions- a freely accessible model code for Europe. Atmos. Chem. Phys. 2011, 11, 5221-5236. doi:10.5194/acp-11-5221-2011. [CrossRef]

141. Singles, R.; Sutton, M.; Weston, K. A multi-layer model to describe the atmospheric transport and deposition of ammonia in Great Britain. Atmos. Environ. 1998, 32, 393-399. doi:10.1016/S1352-2310(97)83467-X. [CrossRef]

142. Kryza, M.; Dore, A.J.; Błaś, M.; Sobik, M. Modelling deposition and air concentration of reduced nitrogen in Poland and sensitivity to variability in annual meteorology. J. Environ. Manag. 2011, 92, 1225-1236. doi:10.1016/j.jenvman.2010.12.008. [CrossRef] [PubMed]

143. Zhang, Y.; Dore, A.J.; Liu, X.; Zhang, F. Simulation of nitrogen deposition in the North China Plain by the FRAME model. Biogeosciences 2011, 8, 3319-3329. doi:10.5194/bg-8-3319-2011. [CrossRef]

144. Redington, A.L.; Derwent, R.G. Calculation of sulphate and nitrate aerosol concentrations over Europe using a Lagrangian dispersion model. Atmos. Environ. 2002, 36, 4425-4439. doi:10.1016/s1352-2310(02)00420-x. [CrossRef]

145. Makar, P.A.; Moran, M.D.; Zheng, Q.; Cousineau, S.; Sassi, M.; Duhamel, A.; Besner, M.; Davignon, D.; Crevier, L.P.; Bouchet, V.S. Modelling the impacts of ammonia emissions reductions on North American air quality. Atmos. Chem. Phys. 2009, 9, 7183-7212. doi:10.5194/acp-9-7183-2009. [CrossRef]

146. van Pul, W.; van Jaarsveld, J.; Vellinga, O.; van den Broek, M.; Smits, M. The VELD experiment: An evaluation of the ammonia emissions and concentrations in an agricultural area. Atmos. Environ. 2008, 42, 8086-8095. doi:10.1016/j.atmosenv.2008.05.069. [CrossRef]

147. Stolk, A.; Van Zanten, M.; Noordijk, H.; Van Jaarsveld, J.; van Pul, W. Measurements of Ammonia in Nature Areas; Data of 2005-2007 Tech Report; Rijksinstituut voor Volksgezondheid en Milieu (RIVM): Utrecht, The Netherlands, 2009.

148. Kruit, R.J.W.; Aben, J.; de Vries, W.; Sauter, F.; van der Swaluw, E.; van Zanten, M.C.; van Pul, W.A.J. Modelling trends in ammonia in the Netherlands over the period 1990-2014. Atmos. Environ. 2017, 154, 20-30. doi:10.1016/j.atmosenv.2017.01.031. [CrossRef]

149. Wen, D.; Lin, J.; Zhang, L.; Vet, R.; Moran, M. Modeling atmospheric ammonia and ammonium using a stochastic Lagrangian air quality model (STILT-Chem v0. 7). Geosci. Model Dev. 2013, 6, 327-344. doi:10.5194/gmd-6-327-2013. [CrossRef] 
150. Gilliland, A.B.; Dennis, R.L.; Roselle, S.J.; Pierce, T.E. Seasonal $\mathrm{NH}_{3}$ emission estimates for the eastern United States based on ammonium wet concentrations and an inverse modeling method. J. Geophys. Res. Atmos. 2003, 108. doi:10.1029/2002jd003063. [CrossRef]

151. Frohn, L. A Study of Long-Term High-Resolution Air Pollution Modelling. Ph.D. Thesis, Aarhus Universtet, Aarhus, Denmark, 2004.

152. Walker, J.M.; Philip, S.; Martin, R.V.; Seinfeld, J.H. Simulation of nitrate, sulfate, and ammonium aerosols over the United States. Atmos. Chem. Phys. 2012, 12, 11213-11227. doi:10.5194/acp-12-11213-2012. [CrossRef]

153. Zhang, L.; Jacob, D.J.; Knipping, E.M.; Kumar, N.; Munger, J.W.; Carouge, C.C.; van Donkelaar, A.; Wang, Y.X.; Chen, D. Nitrogen deposition to the United States: distribution, sources, and processes. Atmos. Chem. Phys. 2012, 12, 4539-4554. doi:10.5194/acp-12-4539-2012. [CrossRef]

154. Paulot, F.; Jacob, D.J.; Johnson, M.T.; Bell, T.G.; Baker, A.R.; Keene, W.C.; Lima, I.D.; Doney, S.C.; Stock, C.A. Global oceanic emission of ammonia: Constraints from seawater and atmospheric observations. Glob. Biogeochem. Cycles 2015, 29, 1165-1178. doi:10.1002/2015gb005106. [CrossRef]

155. Zhu, L.; Henze, D.; Bash, J.; Jeong, G.R.; Cady-Pereira, K.; Shephard, M.; Luo, M.; Paulot, F.; Capps, S. Global evaluation of ammonia bidirectional exchange and livestock diurnal variation schemes. Atmos. Chem. Phys. 2015, 15, 12823-12843. doi:10.5194/acp-15-12823-2015. [CrossRef]

156. Schiferl, L.D.; Heald, C.L.; Damme, M.V.; Clarisse, L.; Clerbaux, C.; Coheur, P.F.; Nowak, J.B.; Neuman, J.A.; Herndon, S.C.; Roscioli, J.R.; et al. Interannual variability of ammonia concentrations over the United States: sources and implications. Atmos. Chem. Phys. 2016, 16, 12305-12328. doi:10.5194/acp-16-12305-2016. [CrossRef]

157. Yu, F.; Nair, A.A.; Luo, G. Long-term trend of gaseous ammonia over the United States: Modeling and comparison with observations. J. Geophys. Res. Atmos. 2018. doi:10.1029/2018JD028412. [CrossRef] [PubMed]

158. Nair, A.A.; Yu, F.; Luo, G. Spatioseasonal Variations of Atmospheric Ammonia Concentrations Over the United States: Comprehensive Model-Observation Comparison. J. Geophys. Res. Atmos. 2019, 124, 6571-6582. doi:10.1029/2018JD030057. [CrossRef]

159. Paulot, F.; Jacob, D.J.; Pinder, R.W.; Bash, J.O.; Travis, K.; Henze, D.K. Ammonia emissions in the United States, European Union, and China derived by high-resolution inversion of ammonium wet deposition data: Interpretation with a new agricultural emissions inventory (MASAGE_NH 3 ). J. Geophys. Res. Atmos. 2014, 119, 4343-4364. doi:10.1002/2013jd021130. [CrossRef]

160. Van Damme, M.; Clarisse, L.; Heald, C.L.; Hurtmans, D.; Ngadi, Y.; Clerbaux, C.; Dolman, A.J.; Erisman, J.W.; Coheur, P.F. Global distributions, time series and error characterization of atmospheric ammonia $\left(\mathrm{NH}_{3}\right)$ from IASI satellite observations. Atmos. Chem. Phys. 2014, 14, 2905-2922. doi:10.5194/acp-14-2905-2014. [CrossRef]

161. Zlatev, Z. Computer Treatment of Large Air Pollution Models; Springer: Dordrecht, The Netherlands, 1995. doi:10.1007/978-94-011-0311-4. [CrossRef]

162. Makar, P.; Bouchet, V.; Nenes, A. Inorganic chemistry calculations using HETV-A vectorized solver for the $\mathrm{SO}_{4}{ }^{2-}-\mathrm{NO}_{3}{ }^{-}-\mathrm{NH}_{4}{ }^{+}$system based on the ISORROPIA algorithms. Atmos. Environ. 2003, 37, 2279-2294. doi:10.1016/S1352-2310(03)00074-8. [CrossRef]

163. Barrett, K.; Seland, Ø.; Foss, A.; Mylona, S.; Sandnes, H.; Styve, H.; Tarrason, L. European Transboundary Acidifying Air Pollution: Ten Years Calculated Fields and Budgets to the End of the First Sulphur Protocol; Technical Report; Norske Meteorologiske Inst.: Oslo, Norway, 1995.

164. Fournier, N.; Pais, V.; Sutton, M.; Weston, K.; Dragosits, U.; Tang, S.; Aherne, J. Parallelisation and application of a multi-layer atmospheric transport model to quantify dispersion and deposition of ammonia over the British Isles. Environ. Pollut. 2002, 116, 95-107. doi:10.1016/S0269-7491(01)00146-4. [CrossRef]

165. Fournier, N.; Tang, Y.S.; Dragosits, U.; Kluizenaar, Y.D.; Sutton, M.A. Regional Atmospheric Budgets of Reduced Nitrogen Over the British Isles Assessed Using a Multi-Layer Atmospheric Transport Model. Water Air Soil Pollut. 2005, 162, 331-351. doi:10.1007/s11270-005-7249-0. [CrossRef]

166. Fournier, N.; Weston, K.J.; Dore, A.J.; Sutton, M.A. Modelling the wet deposition of reduced nitrogen over the British Isles using a Lagrangian multi-layer atmospheric transport model. Q. J. R. Meteorol. Soc. 2005, 131, 703-722. doi:10.1256/qj.04.76. [CrossRef] 
167. Dore, A.; Vieno, M.; Tang, Y.; Dragosits, U.; Dosio, A.; Weston, K.; Sutton, M. Modelling the atmospheric transport and deposition of sulphur and nitrogen over the United Kingdom and assessment of the influence of $\mathrm{SO}_{2}$ emissions from international shipping. Atmos. Environ. 2007, 41, 2355-2367. doi:10.1016/j.atmosenv.2006.11.013. [CrossRef]

168. Sutton, M.; Dragosits, U.; Simmons, I.; Tang, Y.; Hellsten, S.; Love, L.; Vieno, M.; Skiba, U.; di Marco, C.; Storeton-West, R.; et al. Monitoring and modelling trace-gas changes following the 2001 outbreak of Foot and Mouth Disease to reduce the uncertainties in agricultural emissions abatement. Environ. Sci. Policy 2006, 9, 407-422. doi:10.1016/j.envsci.2006.04.001. [CrossRef]

169. Tang, Y.S.; Braban, C.F.; Dragosits, U.; Dore, A.J.; Simmons, I.; van Dijk, N.; Poskitt, J.; Pereira, G.D.S.; Keenan, P.O.; Conolly, C.; et al. Drivers for spatial, temporal and long-term trends in atmospheric ammonia and ammonium in the UK. Atmos. Chem. Phys. 2018, 18, 705-733. doi:10.5194/acp-18-705-2018. [CrossRef]

170. Vieno, M. Use of an Atmospheric Chemistry-Transport Model (FRAME) over the UK and the Development of Its Numerical and Physical Schemes. Ph.D. Thesis, University of Edinburgh, Edinburgh, UK, 2005.

171. Sutton, M.A.; Tang, Y.S.; Dragosits, U.; Fournier, N.; Dore, A.J.; Smith, R.I.; Weston, K.J.; Fowler, D. A Spatial Analysis of Atmospheric Ammonia and Ammonium in the U.K. Sci. World J. 2001, 1, 275-286. doi:10.1100/tsw.2001.313. [CrossRef]

172. Sutton, M.; Milford, C.; Dragosits, U.; Place, C.; Singles, R.; Smith, R.; Pitcairn, C.; Fowler, D.; Hill, J.; ApSimon, H.; et al. Dispersion, deposition and impacts of atmospheric ammonia: quantifying local budgets and spatial variability. Environ. Pollut. 1998, 102, 349-361. doi:10.1016/S0269-7491(98)80054-7. [CrossRef]

173. Hellsten, S.; Dragosits, U.; Place, C.; Vieno, M.; Dore, A.; Misselbrook, T.; Tang, Y.; Sutton, M. Modelling the spatial distribution of ammonia emissions in the UK. Environ. Pollut. 2008, 154, 370-379. doi:10.1016/j.envpol.2008.02.017. [CrossRef]

174. Hallsworth, S.; Dore, A.; Bealey, W.; Dragosits, U.; Vieno, M.; Hellsten, S.; Tang, Y.; Sutton, M. The role of indicator choice in quantifying the threat of atmospheric ammonia to the 'Natura 2000' network. Environ. Sci. Policy 2010, 13, 671-687. doi:10.1016/j.envsci.2010.09.010. [CrossRef]

175. Meng, Z.; Seinfeld, J.H. Time scales to achieve atmospheric gas-aerosol equilibrium for volatile species. Atmos. Environ. 1996, 30, 2889-2900. doi:10.1016/1352-2310(95)00493-9. [CrossRef]

176. van Pul, A.; Jaarsveld, H.V.; van der Meulen, T.; Velders, G. Ammonia concentrations in the Netherlands: spatially detailed measurements and model calculations. Atmos. Environ. 2004, 38, 4045-4055. doi:10.1016/j.atmosenv.2004.03.051. [CrossRef]

177. Van Jaarsveld, J. The Operational Priority Substances Model; Technical Report; Rijksinstituut voor Volksgezondheid en Milieu (RIVM): Utrecht, The Netherlands, 2004.

178. Van der Swaluw, E.; Asman, W.A.; van Jaarsveld, H.; Hoogerbrugge, R. Wet deposition of ammonium, nitrate and sulfate in The Netherlands over the period 1992-2008. Atmos. Environ. 2011, 45, 3819-3826. doi:10.1016/j.atmosenv.2011.04.017. [CrossRef]

179. Hoesly, R.M.; Smith, S.J.; Feng, L.; Klimont, Z.; Janssens-Maenhout, G.; Pitkanen, T.; Seibert, J.J.; Vu, L.; Andres, R.J.; Bolt, R.M.; et al. Historical (1750-2014) anthropogenic emissions of reactive gases and aerosols from the Community Emissions Data System (CEDS). Geosci. Model Dev. 2018, 11, 369-408. doi:10.5194/gmd-11-369-2018. [CrossRef]

180. Crippa, M.; Solazzo, E.; Huang, G.; Guizzardi, D.; Koffi, E.; Muntean, M.; Schieberle, C.; Friedrich, R.; Janssens-Maenhout, G. High resolution temporal profiles in the Emissions Database for Global Atmospheric Research. Sci. Data 2020, 7. doi:10.1038/s41597-020-0462-2. [CrossRef] [PubMed]

181. St-Pierre, R.P.; Cunje, A.; Au, A.; Baker, W.; Baratzadeh, P.; Barrigar, O.; Blain, D.; Czerwinski, A.; Dasné, S.; Earle, J.; et al. Canada's Air Pollutant Emissions Inventory Report 1990-2018; Environment and Climate Change Canada: Gatineau, QC, Canada, 2020.

182. Reis, S.; Pinder, R.W.; Zhang, M.; Lijie, G.; Sutton, M.A. Reactive nitrogen in atmospheric emission inventories. Atmos. Chem. Phys. 2009, 9, 7657-7677. doi:10.5194/acp-9-7657-2009. [CrossRef]

183. Velthof, G.; van Bruggen, C.; Groenestein, C.; de Haan, B.; Hoogeveen, M.; Huijsmans, J. A model for inventory of ammonia emissions from agriculture in The Netherlands. Atmos. Environ. 2012, 46, 248-255. doi:10.1016/j.atmosenv.2011.09.075. [CrossRef] 
184. Li, M.; Zhang, Q.; ichi Kurokawa, J.; Woo, J.H.; He, K.; Lu, Z.; Ohara, T.; Song, Y.; Streets, D.G.; Carmichael, G.R.; et al. MIX: a mosaic Asian anthropogenic emission inventory under the international collaboration framework of the MICS-Asia and HTAP. Atmos. Chem. Phys. 2017, 17, 935-963. doi:10.5194/acp-17-935-2017. [CrossRef]

185. Kurokawa, J.; Ohara, T. Long-term historical trends in air pollutant emissions in Asia: Regional Emission inventory in ASia (REAS) version 3.1. Atmos. Chem. Phys. Discuss. 2019, 2019, 1-51. doi:10.5194/acp-2019-1122. [CrossRef]

186. Klimont, Z.; Cofala, J.; Schöpp, W.; Amann, M.; Streets, D.; Ichikawa, Y.; Fujita, S. Projections of $\mathrm{SO}_{2}$, $\mathrm{NO}_{x}, \mathrm{NH}_{3}$ and VOC Emissions in East Asia Up to 2030. Water Air Soil Pollut. 2001, 130, 193-198. doi:10.1023/a:1013886429786. [CrossRef]

187. Ohara, T.; Akimoto, H.; Kurokawa, J.; Horii, N.; Yamaji, K.; Yan, X.; Hayasaka, T. An Asian emission inventory of anthropogenic emission sources for the period 1980-2020. Atmos. Chem. Phys. 2007, 7, 4419-4444. doi:10.5194/acp-7-4419-2007. [CrossRef]

188. Yamaji, K.; Ohara, T.; Akimoto, H. Regional-specific emission inventory for $\mathrm{NH}_{3}, \mathrm{~N}_{2} \mathrm{O}$, and $\mathrm{CH}_{4}$ via animal farming in South, Southeast, and East Asia. Atmos. Environ. 2004, 38, 7111-7121. doi:10.1016/j.atmosenv.2004.06.045. [CrossRef]

189. Dianwu, Z.; Anpu, W. Estimation of anthropogenic ammonia emissions in asia. Atmos. Environ. 1994, 28, 689-694. doi:10.1016/1352-2310(94)90045-0. [CrossRef]

190. Kurokawa, J.; Ohara, T.; Morikawa, T.; Hanayama, S.; Janssens-Maenhout, G.; Fukui, T.; Kawashima, K.; Akimoto, H. Emissions of air pollutants and greenhouse gases over Asian regions during 2000-2008: Regional Emission inventory in ASia (REAS) version 2. Atmos. Chem. Phys. 2013, 13, 11019-11058. doi:10.5194/acp-13-11019-2013. [CrossRef]

191. Marais, E.A.; Wiedinmyer, C. Air Quality Impact of Diffuse and Inefficient Combustion Emissions in Africa (DICE-Africa). Environ. Sci. Technol. 2016, 50, 10739-10745. doi:10.1021/acs.est.6b02602. [CrossRef] [PubMed]

192. Battye, W.; Aneja, V.P.; Roelle, P.A. Evaluation and improvement of ammonia emissions inventories. Atmos. Environ. 2003, 37, 3873-3883. doi:10.1016/S1352-2310(03)00343-1. [CrossRef]

193. Zheng, J.Y.; Yin, S.S.; Kang, D.W.; Che, W.W.; Zhong, L.J. Development and uncertainty analysis of a high-resolution $\mathrm{NH}_{3}$ emissions inventory and its implications with precipitation over the Pearl River Delta region, China. Atmos. Chem. Phys. 2012, 12, 7041-7058. doi:10.5194/acp-12-7041-2012. [CrossRef]

194. Yu, X.; Shen, L.; Hou, X.; Yuan, L.; Pan, Y.; An, J.; Yan, S. High-resolution anthropogenic ammonia emission inventory for the Yangtze River Delta, China. Chemosphere 2020, 251, 126342. doi:10.1016/j.chemosphere.2020.126342. [CrossRef]

195. Asman, W.A.H.; Sutton, M.A.; Schjorring, J.K. Ammonia: emission, atmospheric transport and deposition. New Phytol. 1998, 139, 27-48. doi:10.1046/j.1469-8137.1998.00180.x. [CrossRef]

196. Battye, R.; Battye, W.; Overcash, C.; Fudge, S. Development and Selection of Ammonia Emission Factors; Technical Report; US Environmental Protection Agency, Atmospheric Research and Exposure Assessment Laboratory: Washington, DC, USA, 1994.

197. Aneja, V.P.; Murray, G.C.; Southerland, J. Atmospheric nitrogen compounds: emissions, transport, transformation, deposition and assessment. Environ. Manage. 1998, 1998, 22-25. [CrossRef]

198. Aneja, V.P.; Chauhan, J.P.; Walker, J.T. Characterization of atmospheric ammonia emissions from swine waste storage and treatment lagoons. J. Geophys. Res. Atmos. 2000, 105, 11535-11545. doi:10.1029/2000JD900066. [CrossRef]

199. Aneja, V.P.; Roelle, P.A.; Murray, G.C.; Southerland, J.; Erisman, J.W.; Fowler, D.; Asman, W.A.; Patni, N. Atmospheric nitrogen compounds II: emissions, transport, transformation, deposition and assessment. Atmos. Environ. 2001, 35, 1903-1911. doi:10.1016/s1352-2310(00)00543-4. [CrossRef]

200. Aneja, V.P.; Nelson, D.R.; Roelle, P.A.; Walker, J.T.; Battye, W. Agricultural ammonia emissions and ammonium concentrations associated with aerosols and precipitation in the southeast United States. J. Geophys. Res. Atmos. 2003, 108, 12.1-12.11. doi:10.1029/2002JD002271. [CrossRef]

201. Sutton, M.A.; Reis, S.; Riddick, S.N.; Dragosits, U.; Nemitz, E.; Theobald, M.R.; Tang, Y.S.; Braban, C.F.; Vieno, M.; Dore, A.J.; et al. Towards a climate-dependent paradigm of ammonia emission and deposition. Philos. Trans. R. Soc. Biol. Sci. 2013, 368, 20130166. doi:10.1098/rstb.2013.0166. [CrossRef] [PubMed] 
202. Olivier, J.; Bouwman, A.; der Hoek, K.V.; Berdowski, J. Global air emission inventories for anthropogenic sources of $\mathrm{NO}_{x}, \mathrm{NH}_{3}$ and $\mathrm{N}_{2} \mathrm{O}$ in 1990. Environ. Pollut. 1998, 102, 135-148. doi:10.1016/s0269-7491(98)80026-2. [CrossRef]

203. Van Der Hoek, K. Estimating ammonia emission factors in Europe: Summary of the work of the UNECE ammonia expert panel. Atmos. Environ. 1998, 32, 315-316. doi:10.1016/S1352-2310(97)00168-4. [CrossRef]

204. Li, C.; Martin, R.V.; Shephard, M.W.; Cady-Pereira, K.; Cooper, M.J.; Kaiser, J.; Lee, C.J.; Zhang, L.; Henze, D.K. Assessing the Iterative Finite Difference Mass Balance and 4D-Var Methods to Derive Ammonia Emissions Over North America Using Synthetic Observations. J. Geophys. Res. Atmos. 2019, 124, 4222-4236. doi:10.1029/2018jd030183. [CrossRef]

205. Zhang, L.; Chen, Y.; Zhao, Y.; Henze, D.K.; Zhu, L.; Song, Y.; Paulot, F.; Liu, X.; Pan, Y.; Lin, Y.; et al. Agricultural ammonia emissions in China: reconciling bottom-up and top-down estimates. Atmos. Chem. Phys. 2018, 18, 339-355. doi:10.5194/acp-18-339-2018. [CrossRef]

206. Bassett, M.; Seinfeld, J.H. Atmospheric equilibrium model of sulfate and nitrate aerosols. Atmos. Environ. 1983, 17, 2237-2252. doi:10.1016/0004-6981(83)90221-4. [CrossRef]

207. Bassett, M.E.; Seinfeld, J.H. Atmospheric equilibrium model of sulfate and nitrate aerosols-II. Particle size analysis. Atmos. Environ. 1984, 18, 1163-1170. doi:10.1016/0004-6981(84)90147-1. [CrossRef]

208. Binkowski, F.S.; Shankar, U. The Regional Particulate Matter Model: 1. Model description and preliminary results. J. Geophys. Res. 1995, 100, 26191. doi:10.1029/95jd02093. [CrossRef]

209. Binkowski, F.S.; Roselle, S.J. Models-3 Community Multiscale Air Quality (CMAQ) model aerosol component 1. Model description. J. Geophys. Res. Atmos. 2003, 108. doi:10.1029/2001jd001409. [CrossRef]

210. Pilinis, C.; Seinfeld, J.H. Continued development of a general equilibrium model for inorganic multicomponent atmospheric aerosols. Atmos. Environ. 1987, 21, 2453-2466. doi:10.1016/0004-6981(87)90380-5. [CrossRef]

211. Kim, Y.P.; Seinfeld, J.H.; Saxena, P. Atmospheric Gas-Aerosol Equilibrium I. Thermodynamic Model. Aerosol Sci. Technol. 1993, 19, 157-181. doi:10.1080/02786829308959628. [CrossRef]

212. Wexler, A.S.; Seinfeld, J.H. Second-generation inorganic aerosol model. Atmos. Environ. Part A Gener. Top. 1991, 25, 2731-2748. doi:10.1016/0960-1686(91)90203-j. [CrossRef]

213. Clegg, S.L.; Brimblecombe, P.; Wexler, A.S. Thermodynamic Model of the System $\mathrm{H}^{+}-\mathrm{NH}_{4}{ }^{+}-\mathrm{SO}_{4}{ }^{2-}-\mathrm{NO}_{3}{ }^{-}-\mathrm{H}_{2} \mathrm{O}$ at Tropospheric Temperatures. J. Phys. Chem. A 1998, 102, 2137-2154. doi:10.1021/jp973042r. [CrossRef]

214. Ansari, A. Prediction of multicomponent inorganic atmospheric aerosol behavior. Atmos. Environ. 1999, 33, 745-757. doi:10.1016/s1352-2310(98)00221-0. [CrossRef]

215. Nenes, A.; Pandis, S.N.; Pilinis, C. ISORROPIA: A new thermodynamic equilibrium model for multiphase multicomponent inorganic aerosols. Aquat. Geochem. 1998, 4, 123-152. doi:10.1023/A:1009604003981. [CrossRef]

216. Fountoukis, C.; Nenes, A. ISORROPIA II: A computationally efficient thermodynamic equilibrium model for $\mathrm{K}^{+}-\mathrm{Ca}^{2+}-\mathrm{Mg}^{2+}-\mathrm{NH}_{4}{ }^{+}-\mathrm{Na}^{+}-\mathrm{SO}_{4}{ }^{2-}-\mathrm{NO}_{3}{ }^{-}-\mathrm{Cl}^{-}-\mathrm{H}_{2} \mathrm{O}$ aerosols. Atmos. Chem. Phys. 2007, 7, 4639-4659. doi:10.5194/acp-7-4639-2007. [CrossRef]

217. Jacobson, M.Z.; Tabazadeh, A.; Turco, R.P. Simulating equilibrium within aerosols and nonequilibrium between gases and aerosols. J. Geophys. Res. Atmos. 1996, 101, 9079-9091. doi:10.1029/96jd00348. [CrossRef]

218. Jacobson, M.Z. Studying the effects of calcium and magnesium on size-distributed nitrate and ammonium with EQUISOLV II. Atmos. Environ. 1999, 33, 3635-3649. doi:10.1016/s1352-2310(99)00105-3. [CrossRef]

219. Zaveri, R.A.; Easter, R.C.; Peters, L.K. A computationally efficient Multicomponent Equilibrium Solver for Aerosols (MESA). J. Geophys. Res. 2005, 110. doi:10.1029/2004jd005618. [CrossRef]

220. Topping, D.O.; McFiggans, G.B.; Coe, H. A curved multi-component aerosol hygroscopicity model framework: Part 1-Inorganic compounds. Atmos. Chem. Phys. 2005, 5, 1205-1222. doi:10.5194/acp-5-1205-2005. [CrossRef]

221. Amundson, N.R.; Caboussat, A.; He, J.W.; Martynenko, A.V.; Savarin, V.B.; Seinfeld, J.H.; Yoo, K.Y. A new inorganic atmospheric aerosol phase equilibrium model (UHAERO). Atmos. Chem. Phys. 2006, 6, 975-992. doi:10.5194/acp-6-975-2006. [CrossRef]

222. Pilinis, C. Modeling atmospheric aerosols using thermodynamic arguments-A Review. Glob. Nest Int. J. 1999, 1, 5-13. doi:10.30955/gnj.000103. [CrossRef] 
223. Zhang, Y.; Seigneur, C.; Seinfeld, J.H.; Jacobson, M.; Clegg, S.L.; Binkowski, F.S. A comparative review of inorganic aerosol thermodynamic equilibrium modules: Similarities, differences, and their likely causes. Atmos. Environ. 2000, 34, 117-137. doi:10.1016/s1352-2310(99)00236-8. [CrossRef]

224. Jacobson, M.Z. Numerical Techniques to Solve Condensational and Dissolutional Growth Equations When Growth is Coupled to Reversible Reactions. Aerosol Sci. Technol. 1997, 27, 491-498. doi:10.1080/02786829708965489. [CrossRef]

225. Jacobson, M.Z. Development and application of a new air pollution modeling system-II. Aerosol module structure and design. Atmos. Environ. 1997, 31, 131-144. doi:10.1016/1352-2310(96)00202-6. [CrossRef]

226. Meng, Z.; Dabdub, D.; Seinfeld, J.H. Size-resolved and chemically resolved model of atmospheric aerosol dynamics. J. Geophys. Res. Atmos. 1998, 103, 3419-3435. doi:10.1029/97jd02796. [CrossRef]

227. Sun, Q.; Wexler, A.S. Modeling urban and regional aerosols—condensation and evaporation near acid neutrality. Atmos. Environ. 1998, 32, 3527-3531. doi:10.1016/s1352-2310(98)00059-4. [CrossRef]

228. Pilinis, C.; Capaldo, K.P.; Nenes, A.; Pandis, S.N. MADM-A New Multicomponent Aerosol Dynamics Model. Aerosol Sci. Technol. 2000, 32, 482-502. doi:10.1080/027868200303597. [CrossRef]

229. Capaldo, K.P.; Pilinis, C.; Pandis, S.N. A computationally efficient hybrid approach for dynamic gas/aerosol transfer in air quality models. Atmos. Environ. 2000, 34, 3617-3627. doi:10.1016/s1352-2310(00)00092-3. [CrossRef]

230. Koo, B.; Gaydos, T.M.; Pandis, S.N. Evaluation of the Equilibrium, Dynamic, and Hybrid Aerosol Modeling Approaches. Aerosol Sci. Technol. 2003, 37, 53-64. doi:10.1080/02786820300893. [CrossRef]

231. Gaydos, T.M.; Koo, B.; Pandis, S.N.; Chock, D.P. Development and application of an efficient moving sectional approach for the solution of the atmospheric aerosol condensation/evaporation equations. Atmos. Environ. 2003, 37, 3303-3316. doi:10.1016/s1352-2310(03)00267-x. [CrossRef]

232. Tombette, M.; Sportisse, B. Aerosol modeling at a regional scale: Model-to-data comparison and sensitivity analysis over Greater Paris. Atmos. Environ. 2007, 41, 6941-6950. doi:10.1016/j.atmosenv.2006.10.037. [CrossRef]

233. Paulot, F.; Jacob, D.J.; Henze, D.K. Sources and Processes Contributing to Nitrogen Deposition: An Adjoint Model Analysis Applied to Biodiversity Hotspots Worldwide. Environ. Sci. Technol. 2013, 47, 3226-3233. doi:10.1021/es3027727. [CrossRef]

234. Behera, S.N.; Sharma, M.; Aneja, V.P.; Balasubramanian, R. Ammonia in the atmosphere: A review on emission sources, atmospheric chemistry and deposition on terrestrial bodies. Environ. Sci. Pollut. Res. 2013, 20, 8092-8131. doi:10.1007/s11356-013-2051-9. [CrossRef]

235. Massad, R.S.; Nemitz, E.; Sutton, M.A. Review and parameterisation of bi-directional ammonia exchange between vegetation and the atmosphere. Atmos. Chem. Phys. 2010, 10, 10359-10386. doi:10.5194/acp-10-10359-2010. [CrossRef]

236. Zhang, L.; Wright, L.P.; Asman, W.A.H. Bi-directional air-surface exchange of atmospheric ammonia: A review of measurements and a development of a big-leaf model for applications in regional-scale air-quality models. J. Geophys. Res. 2010, 115. doi:10.1029/2009jd013589. [CrossRef]

237. Langford, A.O.; Fehsenfeld, F.C. Natural Vegetation as a Source or Sink for Atmospheric Ammonia: A Case Study. Science 1992, 255, 581-583. doi:10.1126/science.255.5044.581. [CrossRef]

238. Sutton, M.A.; Nemitz, E.; Milford, C.; Campbell, C.; Erisman, J.W.; Hensen, A.; Cellier, P.; David, M.; Loubet, B.; Personne, E.; et al. Dynamics of ammonia exchange with cut grassland: synthesis of results and conclusions of the GRAMINAE Integrated Experiment. Biogeosciences 2009, 6, 2907-2934. doi:10.5194/bg-6-2907-2009. [CrossRef]

239. Sutton, M.; Nemitz, E.; Erisman, J.; Beier, C.; Bahl, K.B.; Cellier, P.; de Vries, W.; Cotrufo, F.; Skiba, U.; Marco, C.D.; et al. Challenges in quantifying biosphere-atmosphere exchange of nitrogen species. Environ. Pollut. 2007, 150, 125-139. doi:10.1016/j.envpol.2007.04.014. [CrossRef] [PubMed]

240. Sutton, M.A.; Burkhardt, J.K.; Guerin, D.; Nemitz, E.; Fowler, D. Development of resistance models to describe measurements of bi-directional ammonia surface-atmosphere exchange. Atmos. Environ. 1998, 32, 473-480. doi:10.1016/s1352-2310(97)00164-7. [CrossRef]

241. Nemitz, E.; Milford, C.; Sutton, M.A. A two-layer canopy compensation point model for describing bi-directional biosphere-atmosphere exchange of ammonia. Q. J. R. Meteorol. Soc. 2001, 127, 815-833. doi:10.1002/qj.49712757306. [CrossRef] 
242. Cooter, E.J.; Bash, J.O.; Walker, J.T.; Jones, M.; Robarge, W. Estimation of NH3 bi-directional flux from managed agricultural soils. Atmos. Environ. 2010, 44, 2107-2115. doi:10.1016/j.atmosenv.2010.02.044. [CrossRef]

243. Kruit, R.J.W.; Schaap, M.; Sauter, F.J.; van Zanten, M.C.; van Pul, W.A.J. Modeling the distribution of ammonia across Europe including bi-directional surface-atmosphere exchange. Biogeosciences 2012, 9, 5261-5277. doi:10.5194/bg-9-5261-2012. [CrossRef]

244. Bash, J.O.; Cooter, E.J.; Dennis, R.L.; Walker, J.T.; Pleim, J.E. Evaluation of a regional air-quality model with bidirectional NH3 exchange coupled to an agroecosystem model. Biogeosciences 2013, 10, 1635-1645. doi:10.5194/bg-10-1635-2013. [CrossRef]

245. Pleim, J.E.; Bash, J.O.; Walker, J.T.; Cooter, E.J. Development and evaluation of an ammonia bidirectional flux parameterization for air quality models. J. Geophys. Res. Atmos. 2013, 118, 3794-3806. doi:10.1002/jgrd.50262. [CrossRef]

246. Park, R.J. Natural and transboundary pollution influences on sulfate-nitrate-ammonium aerosols in the United States: Implications for policy. J. Geophys. Res. 2004, 109. doi:10.1029/2003jd004473. [CrossRef]

247. Luo, G.; Yu, F.; Schwab, J. Revised treatment of wet scavenging processes dramatically improves GEOS-Chem 12.0.0 simulations of surface nitric acid, nitrate, and ammonium over the United States. Geosci. Model Dev. 2019, 12, 3439-3447. doi:10.5194/gmd-12-3439-2019. [CrossRef]

248. Luo, G.; Yu, F.; Moch, J.M. Further improvement of wet process treatments in GEOS-Chem v12.6.0: impact on global distributions of aerosols and aerosol precursors. Geosci. Model Dev. 2020, 13, 2879-2903. doi:10.5194/gmd-13-2879-2020. [CrossRef]

249. Xing, J.; Pleim, J.; Mathur, R.; Pouliot, G.; Hogrefe, C.; Gan, C.M.; Wei, C. Historical gaseous and primary aerosol emissions in the United States from 1990 to 2010. Atmos. Chem. Phys. 2013, 13, 7531-7549. doi:10.5194/acp-13-7531-2013. [CrossRef]

250. Li, Y.; Thompson, T.M.; Damme, M.V.; Chen, X.; Benedict, K.B.; Shao, Y.; Day, D.; Boris, A.; Sullivan, A.P.; Ham, J.; et al. Temporal and spatial variability of ammonia in urban and agricultural regions of northern Colorado, United States. Atmos. Chem. Phys. 2017, 17, 6197-6213. doi:10.5194/acp-17-6197-2017. [CrossRef]

251. Yan, X.; Akimoto, H.; Ohara, T. Estimation of nitrous oxide, nitric oxide and ammonia emissions from croplands in East, Southeast and South Asia. Glob. Chang. Biol. 2003, 9, 1080-1096. doi:10.1046/j.1365-2486.2003.00649.x. [CrossRef]

252. Wang, X.; Mauzerall, D.L.; Hu, Y.; Russell, A.G.; Larson, E.D.; Woo, J.H.; Streets, D.G.; Guenther, A. A high-resolution emission inventory for eastern China in 2000 and three scenarios for 2020. Atmos. Environ. 2005, 39, 5917-5933. doi:10.1016/j.atmosenv.2005.06.051. [CrossRef]

253. Liu, L.; Zhang, X.; Xu, W.; Liu, X.; Li, Y.; Lu, X.; Zhang, Y.; Zhang, W. Temporal characteristics of atmospheric ammonia and nitrogen dioxide over China based on emission data, satellite observations and atmospheric transport modeling since 1980. Atmos. Chem. Phys. 2017, 17, 9365-9378. doi:10.5194/acp-17-9365-2017. [CrossRef]

254. Pan, Y.; Tian, S.; Zhao, Y.; Zhang, L.; Zhu, X.; Gao, J.; Huang, W.; Zhou, Y.; Song, Y.; Zhang, Q.; et al. Identifying Ammonia Hotspots in China Using a National Observation Network. Environ. Sci. Technol. 2018, 52, 3926-3934. doi:10.1021/acs.est.7b05235. [CrossRef]

255. Langford, A.; Fehsenfeld, F.; Zachariassen, J.; Schimel, D. Gaseous ammonia fluxes and background concentrations in terrestrial ecosystems of the United States. Glob. Biogeochem. Cycles 1992, 6, 459-483. doi:10.1029/92GB02123. [CrossRef]

256. Alkezweeny, A.; Laws, G.; Jones, W. Aircraft and ground measurements of ammonia in Kentucky. Atmos. Environ. 1986, 20, 357-360. doi:10.1016/0004-6981(86)90038-7. [CrossRef]

257. Erisman, J.W.; Vermetten, A.W.; Asman, W.A.; Waijers-Ijpelaan, A.; Slanina, J. Vertical distribution of gases and aerosols: The behaviour of ammonia and related components in the lower atmosphere. Atmos. Environ. 1988, 22, 1153-1160. doi:10.1016/0004-6981(88)90345-9. [CrossRef]

258. Buijsman, E.; Aben, J.M.; Elzakker, B.G.V.; Mennen, M.G. An automatic atmospheric ammonia network in the Netherlands set-up and results. Atmos. Environ. 1998, 32, 317-324. doi:10.1016/s1352-2310(97)00233-1. [CrossRef]

259. Walker, J.; Whitall, D.R.; Robarge, W.; Paerl, H.W. Ambient ammonia and ammonium aerosol across a region of variable ammonia emission density. Atmos. Environ. 2004, 38, 1235-1246. doi:10.1016/j.atmosenv.2003.11.027. [CrossRef] 
260. Parmar, R.; Satsangi, G.; Lakhani, A.; Srivastava, S.; Prakash, S. Simultaneous measurements of ammonia and nitric acid in ambient air at Agra $\left(27^{\circ} 10^{\prime} \mathrm{N}\right.$ and $\left.78^{\circ} 05^{\prime} \mathrm{E}\right)$ (India). Atmos. Environ. 2001, 35, 5979-5988. doi:10.1016/s1352-2310(00)00394-0. [CrossRef]

261. Pierson, W.R.; Brachaczek, W.W.; Gorse, R.A.; Japar, S.M.; Norbeck, J.M. On the acidity of dew. J. Geophys. Res. Atmos. 1986, 91, 4083-4096. doi:10.1029/JD091iD03p04083. [CrossRef]

262. Perrino, C.; Catrambone, M.; Bucchianico, A.D.M.D.; Allegrini, I. Gaseous ammonia in the urban area of Rome, Italy and its relationship with traffic emissions. Atmos. Environ. 2002, 36, 5385-5394. doi:10.1016/s1352-2310(02)00469-7. [CrossRef]

263. Ianniello, A.; Spataro, F.; Esposito, G.; Allegrini, I.; Rantica, E.; Ancora, M.P.; Hu, M.; Zhu, T. Occurrence of gas phase ammonia in the area of Beijing (China). Atmos. Chem. Phys. 2010, 10, 9487-9503. doi:10.5194/acp-10-9487-2010. [CrossRef]

264. Gong, L.; Lewicki, R.; Griffin, R.J.; Flynn, J.H.; Lefer, B.L.; Tittel, F.K. Atmospheric ammonia measurements in Houston, TX using an external-cavity quantum cascade laser-based sensor. Atmos. Chem. Phys. 2011, 11, 9721-9733. doi:10.5194/acp-11-9721-2011. [CrossRef]

265. Pandolfi, M.; Amato, F.; Reche, C.; Alastuey, A.; Otjes, R.P.; Blom, M.J.; Querol, X. Summer ammonia measurements in a densely populated Mediterranean city. Atmos. Chem. Phys. 2012, 12, 7557-7575. doi:10.5194/acp-12-7557-2012. [CrossRef]

266. Sharma, S.K.; Mandal, T.K.; Rohtash; Kumar, M.; Gupta, N.C.; Pathak, H.; Harit, R.C.; Saxena, M. Measurement of Ambient Ammonia over the National Capital Region of Delhi, India. Mapan 2014, 29, 165-173. doi:10.1007/s12647-014-0098-9. [CrossRef]

267. Wang, S.; Nan, J.; Shi, C.; Fu, Q.; Gao, S.; Wang, D.; Cui, H.; Saiz-Lopez, A.; Zhou, B. Atmospheric ammonia and its impacts on regional air quality over the megacity of Shanghai, China. Sci. Rep. 2015, 5. doi:10.1038/srep15842. [CrossRef]

268. Ni, J. Mechanistic models of ammonia release from liquid manure: a review. J. Agric. Eng. Res. 1999, 72, 1-17. doi:10.1006/jaer.1998.0342. [CrossRef]

269. Sommer, S.G.; Olesen, J.E.; Christensen, B.T. Effects of temperature, wind speed and air humidity on ammonia volatilization from surface applied cattle slurry. J. Agric. Sci. 1991, 117, 91-100. doi:10.1017/S0021859600079016. [CrossRef]

270. Robarge, W.P.; Walker, J.T.; McCulloch, R.B.; Murray, G. Atmospheric concentrations of ammonia and ammonium at an agricultural site in the southeast United States. Atmos. Environ. 2002, 36, 1661-1674. doi:10.1016/s1352-2310(02)00171-1. [CrossRef]

271. Bari, A.; Ferraro, V.; Wilson, L.R.; Luttinger, D.; Husain, L. Measurements of gaseous $\mathrm{HONO}, \mathrm{HNO}_{3}, \mathrm{SO}_{2}$, $\mathrm{HCl}, \mathrm{NH}_{3}$, particulate sulfate and $\mathrm{PM}_{2.5}$ in New York, NY. Atmos. Environ. 2003, 37, 2825-2835. [CrossRef]

272. Anatolaki, C.; Tsitouridou, R. Atmospheric deposition of nitrogen, sulfur and chloride in Thessaloniki, Greece. Atmos. Res. 2007, 85, 413-428. [CrossRef]

273. Wyers, G.; Duyzer, J. Micrometeorological measurement of the dry deposition flux of sulphate and nitrate aerosols to coniferous forest. Atmos. Environ. 1997, 31, 333-343. [CrossRef]

274. Hoell, J.M.; Harward, C.N.; Williams, B.S. Remote infrared heterodyne radiometer measurements of atmospheric ammonia profiles. Geophys. Res. Lett. 1980, 7, 313-316. [CrossRef]

275. Cadle, S.; Countess, R.; Kelly, N. Nitric acid and ammonia in urban and rural locations. Atmos. Environ. 1982, 16, 2501-2506. [CrossRef]

276. Burkhardt, J.; Sutton, M.; Milford, C.; Storeton-West, R.; Fowler, D. Ammonia concentrations at a site in Southern Scotland from 2yr of continuous measurements. Atmos. Environ. 1998, 32, 325-331. [CrossRef]

277. Alebic-Juretic, A. Airborne ammonia and ammonium within the Northern Adriatic area, Croatia. Environ. Pollut. 2008, 154, 439-447. [CrossRef]

278. Yao, X.; Zhang, L. Trends in atmospheric ammonia at urban, rural, and remote sites across North America. Atmos. Chem. Phys. 2016, 16, 11465-11475. [CrossRef]

279. Hu, Q.; Zhang, L.; Evans, G.J.; Yao, X. Variability of atmospheric ammonia related to potential emission sources in downtown Toronto, Canada. Atmos. Environ. 2014, 99, 365-373. [CrossRef]

280. Tang, Y.S.; Dragosits, U.; van Dijk, N.; Love, L.; Simmons, I.; Sutton, M.A. Assessment of Ammonia and Ammonium Trends and Relationship to Critical Levels in the UK National Ammonia Monitoring Network (NAMN). In Atmospheric Ammonia; Springer: Dordrecht, The Netherlands, 2009; pp. 187-194. [CrossRef] 
281. Ferm, M.; Hellsten, S. Trends in atmospheric ammonia and particulate ammonium concentrations in Sweden and its causes. Atmos. Environ. 2012, 61, 30-39. [CrossRef]

282. Sutton, M.A.; Asman, W.A.H.; Ellermann, T.; Jaarsveld, J.A.V.; Acker, K.; Aneja, V.; Duyzer, J.; Horvath, L.; Paramonov, S.; Mitosinkova, M.; et al. Establishing the Link between Ammonia Emission Control and Measurements of Reduced Nitrogen Concentrations and Deposition. Environ. Monit. Assess. 2003, 82, 149-185. [CrossRef] 